HEAVY METALS IN INDOOR SETTLED DUSTS IN TORONTO, CANADA

by

\author{
Ahmed Al Hejami \\ A thesis \\ presented to Ryerson University \\ in partial fulfillment of the \\ requirements for the degree of \\ Master of Science \\ in the program of \\ Molecular Science
}

MSc. in Chemistry, Al-Nahrain University, Baghdad, Iraq, 1995

Toronto, Ontario, Canada, 2014

(C) Ahmed Al Hejami, 2014 


\section{AUTHOR'S DECLARATION}

\section{AUTHOR'S DECLARATION FOR ELECTRONIC SUBMISSION OF A THESIS}

I hereby declare that I am the sole author of this thesis. This is a true copy of the thesis, including any required final revisions, as accepted by my examiners.

I authorize Ryerson University to lend this thesis to other institutions or individuals for the purpose of scholarly research.

I further authorize Ryerson University to reproduce this thesis by photocopying or by other means, in total or in part, at the request of other institutions or individuals for the purpose of scholarly research.

I understand that my thesis may be made electronically available to the public. 


\begin{abstract}
HEAVY METALS IN INDOOR SETTLED DUSTS IN TORONTO, CANADA
\end{abstract}

\author{
Ahmed Al Hejami \\ Master of Science, Molecular Science, Ryerson University, 2014
}

Total concentrations of nine potentially toxic heavy metals ( $\mathrm{Ba}, \mathrm{Cd}, \mathrm{Cr}, \mathrm{Cu}, \mathrm{Hg}, \mathrm{Mn}, \mathrm{Ni}$, $\mathrm{Pb}$, and $\mathrm{Zn}$ ) in indoor settled dusts from houses, offices, classrooms, and laboratories in Greater Toronto Area, Canada were determined. Mercury concentrations were determined using cold vapor atomic fluorescence spectroscopy (CVAFS), whereas the concentrations of eight other metals were determined using inductively coupled plasma atomic emission spectroscopy (ICPAES). The results showed that the highest level of heavy metals was in the laboratory dusts. Metal concentrations (except those for $\mathrm{Mn}$ and $\mathrm{Zn}$ ) in household, office, and classroom dusts were comparable. $\mathrm{Cd}, \mathrm{Cr}, \mathrm{Cu}, \mathrm{Ni}$, and $\mathrm{Zn}$ concentrations in the laboratory dusts and $\mathrm{Cu}$ and $\mathrm{Zn}$ concentrations in household, office, and classroom dusts exceeded the Canadian Soil Guideline. Metal concentrations in the indoor dusts found in this study were, in general, consistent with those reported in literature. Among the metals studied, $\mathrm{Cd}, \mathrm{Cu}, \mathrm{Hg}, \mathrm{Pb}$, and $\mathrm{Zn}$ showed the greatest enrichment in the indoor environments relative to their crustal abundances. 


\section{ACKNOWLEDGEMENT}

I would like to express my sincere thanks and gratitude to my supervisor, Dr. Julia Lu, for her valuable guidance, encouragement, and help throughout my research. I want to thank my supervisory committee members, Dr. Darrick Heyd, Dr. Daniel Foucher, and Dr. Stephen Wylie, for their feedback and suggestions. I extend my thanks to Dr. Russell Viirre for serving on my examining committee and Dr. Andrew McWilliams for chairing my thesis defense. The help of the previous graduate student in Dr. Lu's lab, Muhammad Yousaf, is also gratefully acknowledged. Furthermore I would like to thank the Molecular Science Graduate Program, Ryerson University for allowing me to conduct my research and providing any assistance requested. I also want to thank Natural Sciences and Engineering Research Council of Canada (NSERC) and Canada Foundation for Innovation (CFI) for their financial support. At the end special thanks go to my wife, Halla Majeed, for her constant love and support throughout my study. 


\section{DEDICATION}

I would like to dedicate my thesis to my wife, Halla, my daughter, Sura, and my son, Hussain. 


\section{TABLE OF CONTENTS}

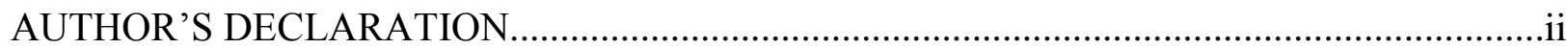

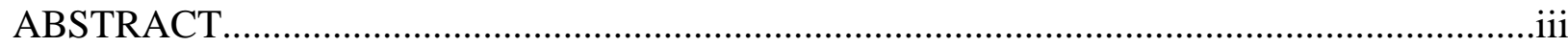

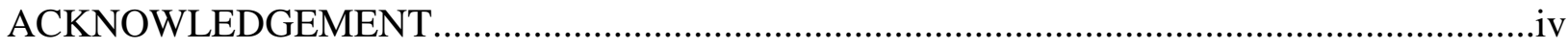

DEDICATION

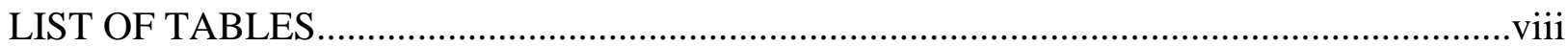

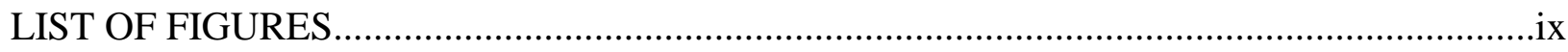

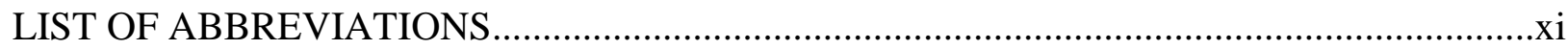

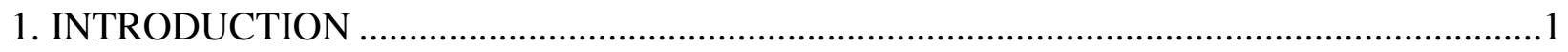

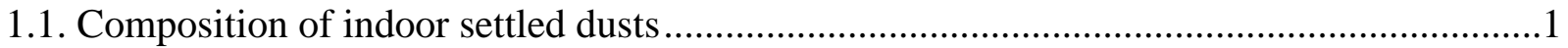

1.2. Sources of heavy metals in indoor settled dusts ...........................................................2

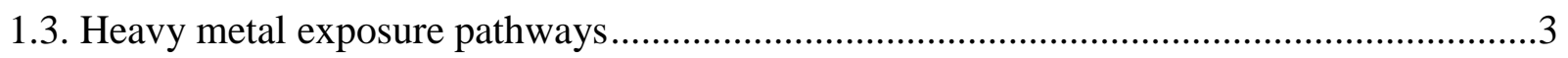

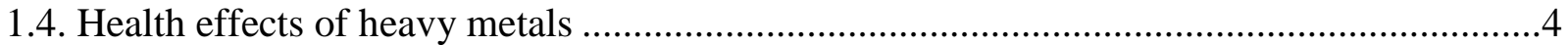

1.5. Literature survey of concentrations of heavy metals in indoor settled dusts .....................4

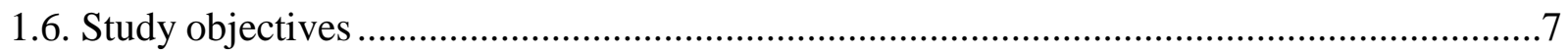

2. MATERIALS AND METHODS

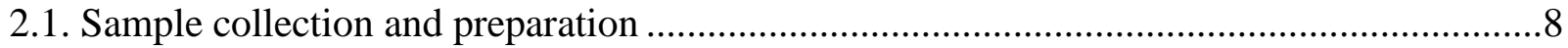

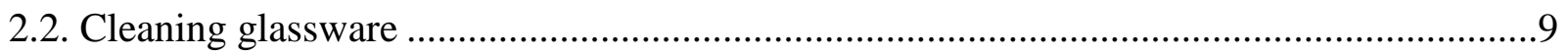

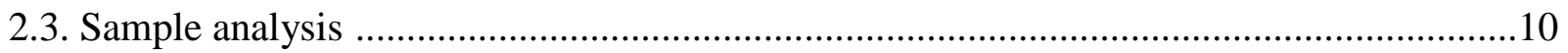

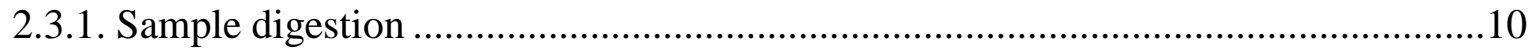

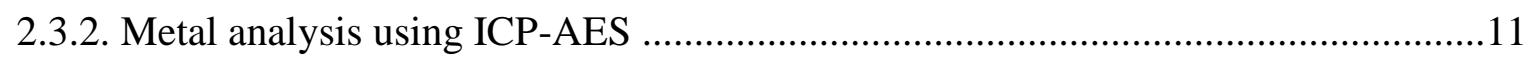

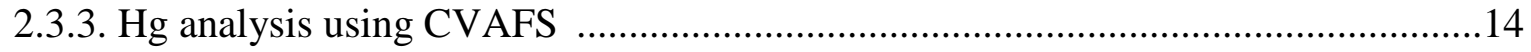

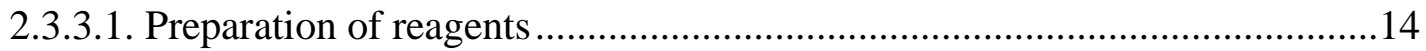

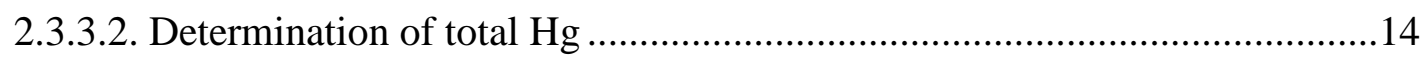

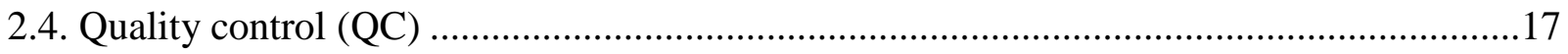

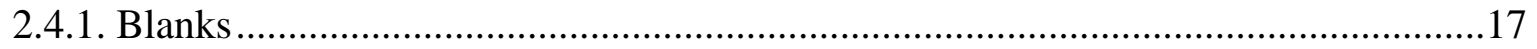

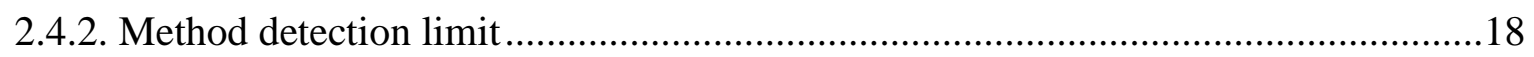


2.4.3. Method validation .................................................................................... 18

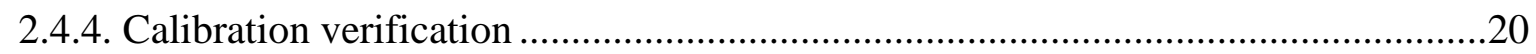

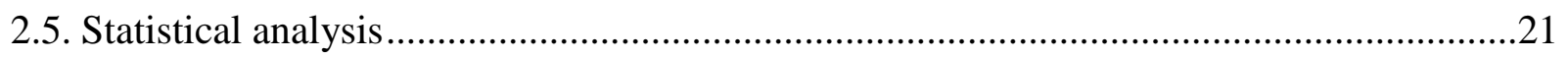

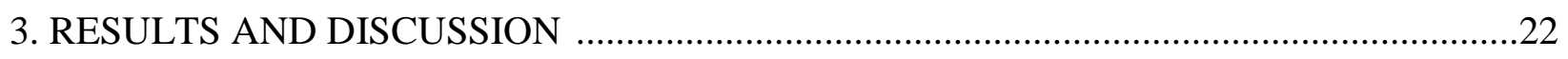

3.1 Heavy metal concentrations in household dusts .......................................................22

3.2 Heavy metal concentrations in office, classroom, and laboratory dusts ..........................29

3.3 Comparison of the results from different indoor environments.....................................31

3.4 Comparison of the results observed in this study with literature values...........................33

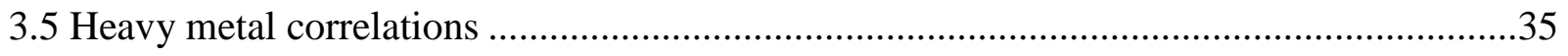

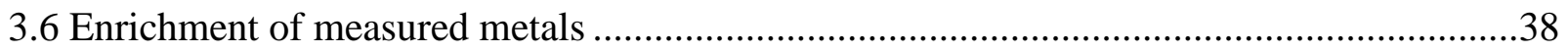

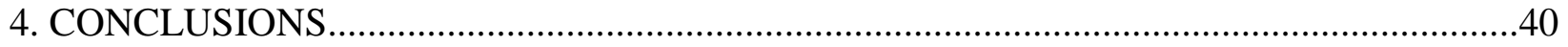

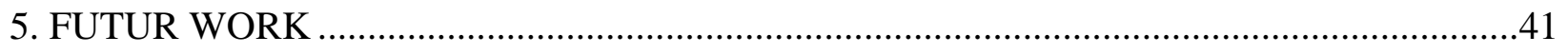

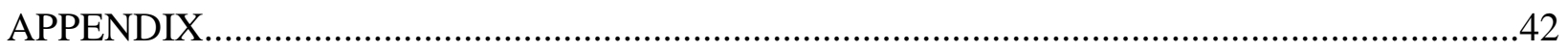

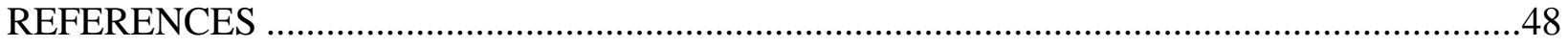




\section{LIST OF TABLES}

Table 1. Recovery and precision for the determination of metals in SRM 2584 (NIST, Trace Element in Indoor Dust) using ICP-AES 19

Table 2. Total metal concentrations ( $\mathrm{mg} \mathrm{kg}^{-1}$, dry weight) in the household dust samples collected in GTA, Canada 23

Table 3. Total metal concentrations ( $\mathrm{mg} \mathrm{kg}^{-1}$, dry weight) in dust samples collected from offices, classrooms, and laboratories in CTA, Canada. 30

Table 4. Comparison of the arithmetic mean concentrations $\left(\mathrm{mg} \mathrm{kg}^{-1}\right)$ of heavy metals in indoor dusts presented in this study with those reported in literature. 34

Table 5. Inter-metal correlations for the household dusts........................................................ 36

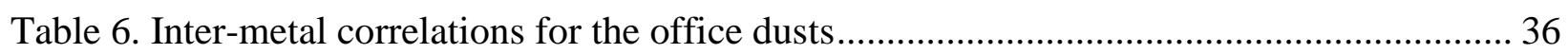

Table 7. Inter-metal correlations for the laboratory dusts......................................................... 37

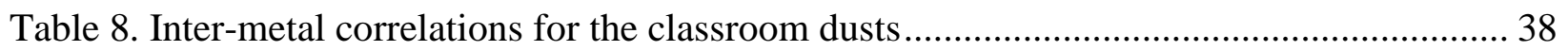

Table 9. Enrichment factors for heavy metals in the indoor dust samples .................................. 39 


\section{LIST OF FIGURES}

Fig. 1. Sampling locations: (A) residential within the Greater Toronto Area (GTA), Canada. Green and red dots represent sampling locations in the winter of 2012 and 2013, respectively; (B) non-residential in the downtown Toronto ................................................. 8

Fig. 2. Sample collection surfaces in the indoor environments ……….................................... 9

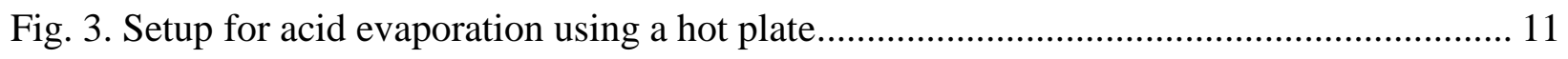

Fig. 4. Clibration curves for heavy metal analysis using ICP-AES .......................................... 13

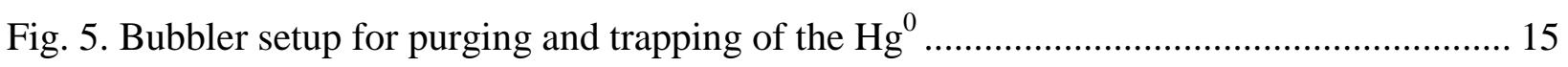

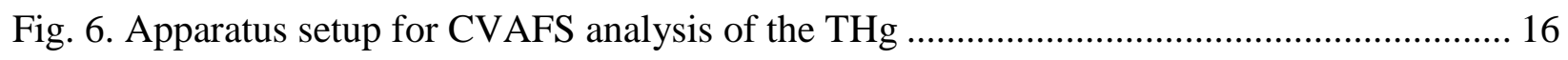

Fig. 7. Comparison of the arithmetic mean concentrations of metals in the household dusts

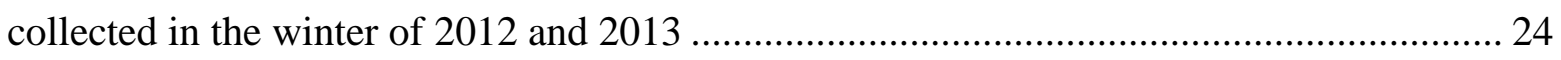

Fig. 8. Geographical distribution of Ba concentrations in the household dusts collected in the

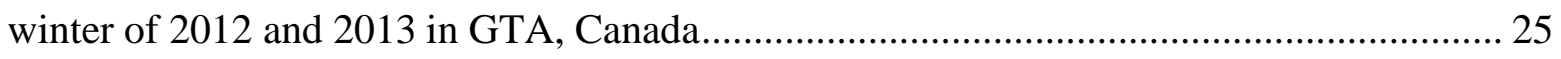

Fig. 9. Geographical distribution of Cd concentrations in the household dusts collected in the

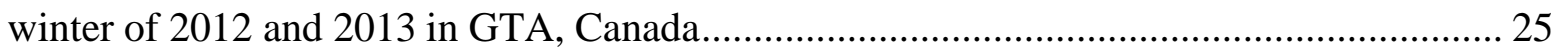

Fig. 10. Geographical distribution of $\mathrm{Cr}$ concentrations in the household dusts collected in the

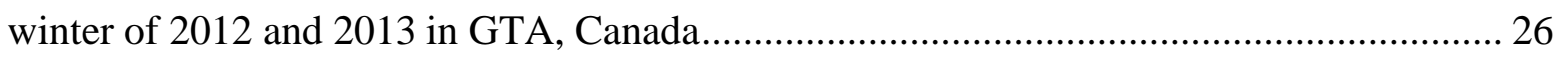

Fig. 11. Geographical distribution of $\mathrm{Cu}$ concentrations in the household dusts collected in the

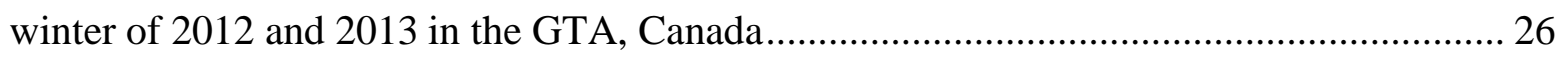

Fig. 12. Geographical distribution of $\mathrm{Hg}$ concentrations in the household dusts collected in the

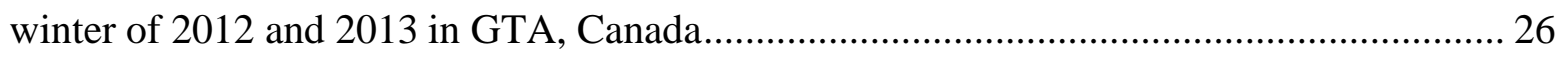


Fig. 13. Geographical distribution of Mn concentrations in the household dusts collected in the winter of 2012 and 2013 in GTA, Canada

Fig. 14. Geographical distribution of Ni concentrations in the household dusts collected in the winter of 2012 and 2013 in GTA, Canada........ 27

Fig. 15. Geographical distribution of $\mathrm{Pb}$ concentrations in the household dusts collected in the winter of 2012 and 2013 in GTA, Canada...... 27

Fig. 16. Geographical distribution of $\mathrm{Zn}$ concentrations in the household dusts collected in the winter of 2012 and 2013 in GTA, Canada....... 28

Fig. 17. Comparison of the arithmetic mean concentrations of metals in the household dusts from downtown Toronto and other regions of GTA, canada 28

Fig. 18. Comparison of the arithmetic mean concentrations of metals in indoor settled dusts collected from different indoor environments: HT = House Total; HD = House Downtown; $\mathrm{L}=$ Laboratory; $\mathrm{O}=$ Office; $\mathrm{C}=$ Classroom 32 


\section{LIST OF ABBREVIATIONS}

\begin{tabular}{|c|c|}
\hline $\mathrm{AM}$ & Arithmetic Mean \\
\hline ANOVA & Analysis of Variance \\
\hline $\mathrm{Ar}$ & Argon \\
\hline $\mathrm{Ba}$ & Barium \\
\hline CCME & Canadian Council of Ministers of the Environment \\
\hline $\mathrm{Cd}$ & Cadmium \\
\hline $\mathrm{CF}$ & Calibration Factor \\
\hline $\mathrm{Cr}$ & Chromium \\
\hline $\mathrm{Cu}$ & Copper \\
\hline CVAFS & Cold Vapor Atomic Fluorescence Spectroscopy \\
\hline $\mathrm{EF}$ & Enrichment Factor \\
\hline GIS & Geographic Information System \\
\hline GM & Geometric Mean \\
\hline GTA & Greater Toronto Area \\
\hline $\mathrm{Hg}$ & Mercury \\
\hline $\mathrm{Hg}^{0}$ & Elemental mercury \\
\hline ICP-AES & Inductively Coupled Plasma Atomic Emission Spectroscopy \\
\hline IPR & Initial Precision and Recovery \\
\hline Max & Maximum \\
\hline MDL & Method Detection Limit \\
\hline
\end{tabular}




\begin{tabular}{|c|c|}
\hline Min & Minimum \\
\hline Mn & Manganese \\
\hline $\mathrm{N}_{2}$ & Nitrogen \\
\hline $\mathrm{Ni}$ & Nickel \\
\hline NIST & National Institute of Standards and Technology \\
\hline $\mathrm{Pb}$ & Lead \\
\hline PVC & Polyvinyl Chloride \\
\hline QC & Quality Control \\
\hline RSD & Relative Standard Deviation \\
\hline SAS & Statistical Analysis Software \\
\hline SD & Standard Deviation \\
\hline SRM & Standard Reference Material \\
\hline SPSS & Statistical Package for Social Science \\
\hline $\mathrm{THg}$ & Total mercury \\
\hline USEPA & United State Environmental Protection Agency \\
\hline $\mathrm{Zn}$ & Zinc \\
\hline
\end{tabular}




\section{INTRODUCTION:}

Indoor air quality is an environmental health concern because people spend up to $90 \%$ of their time indoors in places, such as homes, offices and schools (Klepeis et al. 2001; Sharpe 2004; Health Canada 2009; Tran et al. 2012). Indoor settled dusts contain various hazardous materials including heavy metals, which can affect human health (Dundar and Atundag 2002). Heavy metals in indoor dusts are an important indicator of pollution in urban environments (Lu et al. 2009).

\subsection{Composition of indoor settled dusts:}

Indoor settled dusts can be defined as fine $(\leq 100 \mu \mathrm{m})$ settled airborne particles in the indoor local environment (Turner 2011). Indoor dusts have external and internal sources. External sources include materials, such as outdoor air particles, garden soil and road dusts, brought indoors from the outdoor environment. Internal sources include smoking, combustion processes (e.g., heating, cooking), building materials (e.g., paints), abrasion from indoor items (e.g., paper, carpet and clothing), and parts from indoor living organisms including occupants, pets, bacteria, fungi, and dust mites (Butte and Heinzow 2002). Indoor settled dusts are, therefore, a heterogeneous matrix of organic matter and inorganic materials. The composition of indoor dusts alters markedly with the season (e.g., temperature, indoor air circulation), age of the building, quantity of furniture and carpets as well as their preservation, and the occupants' living habits, including activities and use of personal products (Morawska and Salthammer 2003). 
Consequently, the composition of indoor settled dusts can vary greatly between rooms of a given house and among geographic locations (Lioy et al. 2002).

\subsection{Sources of heavy metals in indoor settled dusts:}

Heavy metals can be defined as trace elements with atomic weights higher than $40.04 \mathrm{~g}$ mol $^{-1}$ (Banfalvi, 2011). Heavy metals, like barium (Ba), cadmium (Cd), chromium (Cr), copper $(\mathrm{Cu})$, mercury $(\mathrm{Hg})$, manganese $(\mathrm{Mn})$, nickel $(\mathrm{Ni})$, lead $(\mathrm{Pb})$, and zinc $(\mathrm{Zn})$, exist in indoor settled dusts originating from internal and external sources and therefore show considerable enrichment in the indoor environments relative to their crustal abundances (Fergusson and Kim 1991, Rasmussen 2004). External sources could be heavy metals associated with particles that are airborne or that are tracked-in on clothing and footwear including soil, road dust, industrial and vehicular particulates (Turner 2011). Automobile emissions are considered as important sources of various heavy metals, including Ba (oil and diesel fuel additives), Cr (chromium plating, alloys), $\mathrm{Cu}$ (metal plating, brake lining), Mn (gasoline additives), Ni (metal parts, oil additives), $\mathrm{Pb}$ (tire and gasoline additives), and $\mathrm{Cd}$ and $\mathrm{Zn}$ (tire and oil additives) (Madany et al. 1994; Lisiewicz et al. 2000; Chattopadhyay et al. 2003; Khoder et al. 2010; Charlesworth et al. 2011).

Important internal sources of heavy metals include decorative paints, consumer and cosmetic products, appliances, rubber carpet backing and carpet pigments, worn construction materials, and combustion products of cooking, heating and smoking (Turner 2011). Paints have been recognized as serious sources of heavy metals. For example, yellow paint is associated with higher concentrations of $\mathrm{Cd}, \mathrm{Cu}, \mathrm{Pb}$, and $\mathrm{Zn}$ in indoor dusts (Tong and Lam 2000; Chattopadhyay et al. 2003). High Cd levels in indoor dusts have also been attributed to carpet 
wear (Kim and Fergusson 1993). Electrical and electronic appliances, such as televisions, washing machines, refrigerators, air conditioners, and personal computers contain significant amounts of heavy metals, including $\mathrm{Ba}, \mathrm{Cd}, \mathrm{Cr}, \mathrm{Cu}, \mathrm{Hg}, \mathrm{Ni}, \mathrm{Pb}$, and $\mathrm{Zn}$. For example, $\mathrm{Cr}$ is used in data tapes and floppy disks; $\mathrm{Cd}$ is used in rechargeable $\mathrm{Ni}-\mathrm{Cd}$ batteries and as stabilizers in polyvinyl chloride (PVC), which is used as insulation coating on wires and cables (Lau et al. 2014). Products containing $\mathrm{Hg}$ include manometers, thermometers, electrical and electronic switches, and fluorescent lamps (Rutagi and Singh 2010; Huang et al. 2012).

\subsection{Heavy metal exposure pathways:}

Indoor settled dusts containing heavy metals are an important source of exposure for people, especially children and other vulnerable individuals. Inhalation, dust ingestion, and dermal contact are common pathways by which toxic heavy metals can enter the body (Morawska and Salthammer 2003). Through breathing, airborne dust particles pose considerable health risks, such as diverse respiratory illnesses, decreased lung function, and cardiovascular diseases (Turner and Hefzi 2010). Heavy metals such as $\mathrm{Cd}, \mathrm{Ni}$, and $\mathrm{Pb}$ are common examples of metals that cause negative health impacts from breathing and have been noticed from both occupational and ambient air exposure (Vincent 2005). Dust ingestion occurs, unwittingly, with food and drink, and with respect to young children via the mouthing of non-food items and repetitive hand-to-mouth activity (Butte and Heinzow 2002). Dermal contact is the other way for exposure of heavy metals. For example, $\mathrm{Ni}$ is classified as a skin sensitizer and it can cause allergic contact dermatitis (Mazinanian et al. 2013). 


\subsection{Health effects of heavy metals:}

Heavy metals are usually non-degradable and their high levels can threaten biological life. Many of them such as $\mathrm{Cu}$ and $\mathrm{Zn}$ have some biological functions at low concentrations and cause toxic effects at higher than physiological concentrations (Banfalvi 2011). Some heavy metals, like $\mathrm{Cd}, \mathrm{Hg}$, and $\mathrm{Pb}$, have no known physiological role in the human body and even at extremely low concentrations, they are toxic and cause various diseases (Willlers et al. 2005). Heavy metals can cause anemia, kidney failure, brain dysfunction, liver cirrhosis, cancer, and cardiovascular diseases (Nriagu 1988). High exposure of $\mathrm{Cd}, \mathrm{Hg}$, and $\mathrm{Pb}$ may lead to the damage of bone, kidneys and the brain (Alfven et al. 2002; Chattapadhyay 2003; Barregard 2006). A number of heavy metals including $\mathrm{Cd}, \mathrm{Cr}, \mathrm{Ni}, \mathrm{Pb}$, and $\mathrm{Zn}$ are recognized as suspected carcinogens (Cook et al. 2005). Mn may cause liver dysfunction, neurologic and neuropsychiatric illnesses (Kramtz and Dorevitch 2004). The presence of $\mathrm{Cu}$ irritates the mucous membranes and disturbs the digestive system (Jabeen et al. 2001). Ba is associated with muscle cramps and interferes with the heartbeat (Khaparde et al. 2012). Some heavy metals (e.g., Ba, Cr, Ni and Zn) may cause asthma (Karntz and Dorevitch 2004; Khaparde et al. 2012).

\subsection{Literature survey of concentrations of heavy metals in indoor settled dusts:}

In recent years, several studies have been conducted to analyze heavy metals in indoor dusts, such as household, office and classroom dusts. The mean concentration values were in the range of $85-492 \mathrm{mg} \mathrm{kg}^{-1}$ for $\mathrm{Ba}, 0.80-6.5 \mathrm{mg} \mathrm{kg}^{-1}$ for $\mathrm{Cd}, 37-254 \mathrm{mg} \mathrm{kg}^{-1}$ for $\mathrm{Cr}, 91-2740 \mathrm{mg} \mathrm{kg}^{-}$ ${ }^{1}$ for $\mathrm{Cu}, 0.20-3.63 \mathrm{mg} \mathrm{kg}^{-1}$ for $\mathrm{Hg}, 76-772 \mathrm{mg} \mathrm{kg}^{-1}$ for $\mathrm{Mn}, 26-471 \mathrm{mg} \mathrm{kg}^{-1}$ for $\mathrm{Ni}, 28-406 \mathrm{mg}$ $\mathrm{kg}^{-1}$ for $\mathrm{Pb}, 396-3104 \mathrm{mg} \mathrm{kg}^{-1}$ for $\mathrm{Zn}$ (Rasmussen et al. 2001; Chattopadhyay et al. 2003; AlMomani 2007; Turner and Hafzi 2010; Kurt-Karakus 2012; Kefeni and Okankwo 2013). 
Hassan (2012) has investigated heavy metals in dusts collected from households, stairs and entryways of some Egyptian homes. The results showed that the highest mean concentrations of $\mathrm{Cd}, \mathrm{Co}, \mathrm{Cr}, \mathrm{Cu}, \mathrm{Ni}$, and $\mathrm{Pb}$ were observed in the entryway, followed by household and stair dusts. The study inferred that in addition to internal sources, heavy metals in household dust could originate from external sources because there was a correlation between the metal concentrations in household and entryway dusts.

Another study (Al-Momani 2007) was conducted to analyze heavy metals in house dust, street dust, and garden soil samples collected from Amman, Jordan. The results showed that the house dusts contained higher concentrations of $\mathrm{Cd}, \mathrm{Cr}, \mathrm{Cu}, \mathrm{Ni}, \mathrm{Pb}$, and $\mathrm{Zn}$ than either street dusts or garden soils. Using diesel fuel for heating by metal furnaces was the main source leading to increase the concentrations of $\mathrm{Ni}, \mathrm{Pb}$, and $\mathrm{Zn}$ in the house dusts.

Chattopadhyay et al. (2003) found that although the concentrations of $\mathrm{Pb}$ in fine airborne particles in Sydney, Australia have decreased since the phasing out of leaded gasoline, the $\mathrm{Pb}$ levels in household dusts have remained constant. This is not due only to building up of $\mathrm{Pb}$ in the house from the old leaded paints, but also the historical accumulation of more than 80 years of leaded gasoline deposition in the urban area.

Rasmussen et al. (2001) have determined multi-element profiles of indoor dusts, exterior dusts and soils collected from 50 residences located in 10 different zones of Ottawa, the capital city of Canada. The study indicated that a significant amount of heavy metals, such as $\mathrm{Cd}, \mathrm{Hg}$, and $\mathrm{Pb}$ in household dusts was generated from sources within the indoor environment. The concentrations of these metals in household dusts were higher than their concentrations in either street dusts or garden soils. Moreover, total metal concentrations in indoor dusts may be 
influenced by the ability of biogenic particles, such as fungi and molds that have built up heavy metals to high levels.

Another study, performed by Tong and Lam (2000), measured heavy metal concentrations in indoor dusts collected from houses across Hong Kong. The study suggested that the significant factors, which may affect heavy metal concentrations in household dusts, were traffic, age of the building, neighborhood, and wall paint.

Household and office dusts from Istanbul, Turkey have been analyzed to quantify $\mathrm{Cd}, \mathrm{Cr}$, $\mathrm{Cu}, \mathrm{Mn}, \mathrm{Ni}, \mathrm{Pb}$ and $\mathrm{Zn}$ (Kurt-Karakus 2012). The results showed that there was no difference between the metal concentrations in household and office dusts. In addition, the authors examined several factors (e.g., age of building, number of occupants, last paint and pets) that might have influenced the concentrations of the heavy metals in the indoor dusts. They found that the number of occupants was the most significant factor affecting concentrations of heavy metals. Kefeni and Okonkwo (2013) have analyzed settled dusts collected from homes and offices in Pretoria, South Africa for evaluating heavy metal concentrations. Their results showed that the office dusts were more contaminated than home dusts.

Popoola et al. (2012) showed that $\mathrm{Cd}, \mathrm{Cr}$ and $\mathrm{Pb}$ were detected in the classroom dust samples collected from primary schools in Lagos State, Nigeria. Although the amounts of the metals were lower than some reported values for dusts in a number of locations worldwide, the metal pollutants in classroom dusts could be an important source of exposure for children because they spend a lot of time in the classroom. Yap et al. (2011), also, examined heavy metals in classroom dusts collected from the ceiling fans in many schools located across Selangor, 
Malaysia. The results showed that some elevated levels of $\mathrm{Cd}, \mathrm{Cu}, \mathrm{Ni}$ and $\mathrm{Pb}$ were related to anthropogenic sources.

From the previous studies, two points can be highlighted. Firstly, concentrations of heavy metals are most likely higher in indoor than outdoor settled dusts. Secondly, the important factors, which may affect the concentrations of heavy metals in indoor dusts, include traffic, building age, building materials, type of heating, neighborhood, number of occupants, ventilation behavior, and certain personal hobbies.

\subsection{Study objectives:}

To our knowledge, no data have been published on heavy metal concentrations in indoor dusts in Toronto, the largest city in Canada. Therefore, this study is the first to report heavy metal concentrations in indoor settled dusts collected from homes, offices, classrooms and laboratories in Greater Toronto Area (GTA).

The main objectives of the present study were:

- To quantify $\mathrm{Ba}, \mathrm{Cd}, \mathrm{Cr}, \mathrm{Cu}, \mathrm{Hg}, \mathrm{Mn}, \mathrm{Ni}, \mathrm{Pb}$, and $\mathrm{Zn}$ in the settled dusts collected from households, offices, classrooms and laboratories.

- To compare the concentrations of the heavy metals in household dusts with office, classroom, and laboratory dusts.

- To use the results to identify "hot spots" of heavy metals in indoor environments in the GTA.

- To compare the results of heavy metal concentrations with the values reported in literature worldwide. 


\section{MATERIALS AND METHODS:}

\subsection{Sample collection and preparation:}

Household settled dust samples were collected from a total of 67 residences from different suburbs within the Greater Toronto Area (Fig. 1A) during January-April, 2012 and January-April, 2013. The dust samples were collected from different rooms including basement, kitchen, dining, living, and bedrooms. Samples of indoor settled dusts from offices, classrooms, and laboratories were collected during January-March, 2014 from the Kerr Hall building at Ryerson University (Fig. 1B) located in the downtown core of Toronto and surrounded by high traffic density roads.

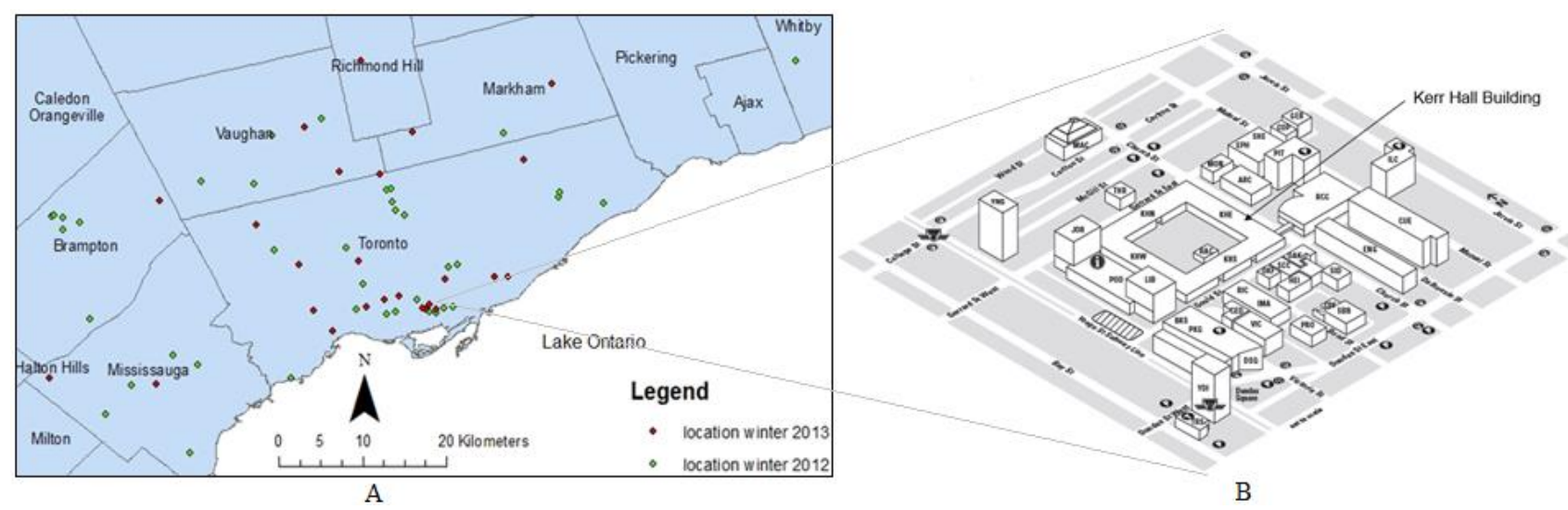

Fig. 1. Sampling locations: (A) residential within the Greater Toronto Area (GTA), Canada. Green and red dots represent sampling locations in the winter of 2012 and 2013, respectively; (B) non-residential in the downtown Toronto.

All dust samples were collected into resealable plastic bags (dimensions: $16.5 \mathrm{~cm} \times$ $8.25 \mathrm{~cm}$ ) by gently sweeping from different surfaces, such as fans, bookshelves, window sills, 
cabinets, refrigerators, projector screens, and fume hoods (Fig. 2). The samples were then double bagged and clearly labelled. Powder free gloves were worn during sample collections.
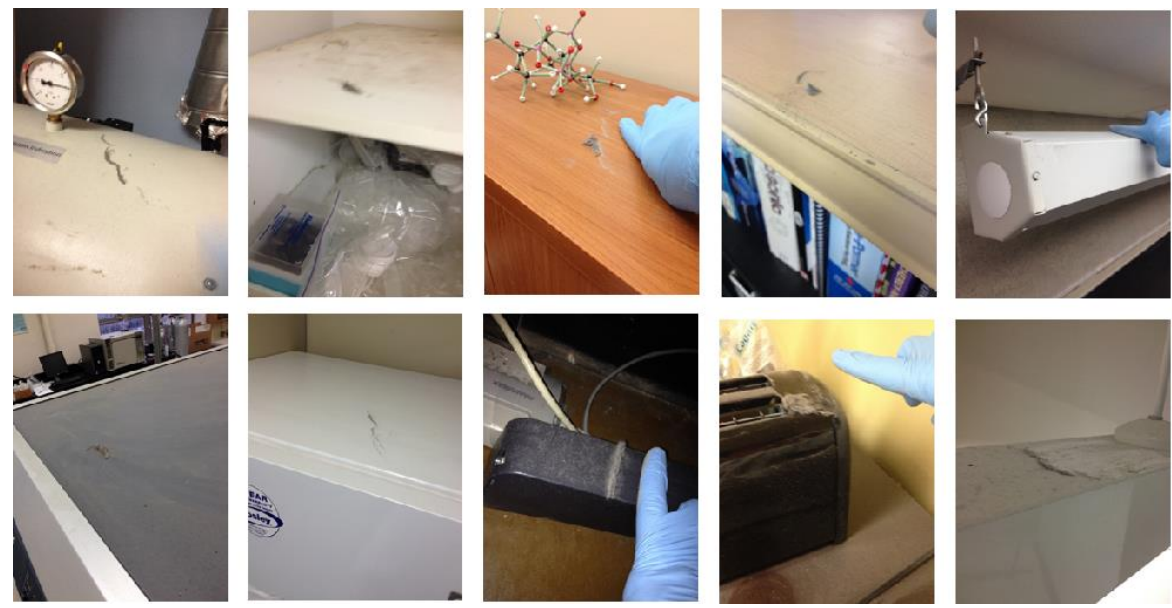

Fig. 2. Sample collection surfaces in the indoor environments.

The dust samples were screened to remove any visible hair, soil, and grit. The samples were then oven-dried at $45^{\circ} \mathrm{C}$ for 48 hours and homogenized using a mortar and pestle. All the results were reported based on dry weight.

\subsection{Cleaning glassware:}

All laboratory glassware and plastic containers were initially cleaned with soap, rinsed thoroughly with tap water, then with distilled water followed by Milli-Q water $(18.2 \mathrm{M} \Omega-\mathrm{cm}$; Barnstead). The containers were filled with $10 \% \mathrm{HNO}_{3}$ (prepared from $67-70 \% \mathrm{HNO}_{3}$; PlasmaPure, SCP Science) for 48 hours to remove any heavy metals contamination. The glassware and plastic containers were then rinsed thoroughly several times and filled with MilliQ water until use. 
Digestion vessels were first filled with soap overnight and then brushed several times with soap, washed thoroughly with tap water, rinsed with distilled water and finally with Milli-Q water. The vessels were filled with 1:1 $\mathrm{HCl}$ (prepared from 34-37\% $\mathrm{HCl}$, PlasmaPure, SCP Science) for 48 hours, then rinsed with Milli-Q water several times and filled with 1:1 $\mathrm{HNO}_{3}$ (prepared from $67-70 \% \mathrm{HNO}_{3}$, PlasmaPure, SCP Science) for 48 hours. Finally, the vessels were rinsed several times and filled with Milli-Q water until use.

\subsection{Sample analysis:}

\subsubsection{Sample digestion:}

Dust samples were digested in a QLAB Pro microwave digestion system (Questron Technologies Corp., Mississauga, Canada). Approximately $0.15 \mathrm{~g}$ of dust sample, $5 \mathrm{~mL}$ of $67-$ $70 \% \mathrm{HNO}_{3}$ (PlasmaPure Plus, SCP Science), and $0.5 \mathrm{~mL}$ of $47-51 \% \mathrm{HF}$ (TraceSELECT ® for trace analysis, Fluka) were added into each lined digested vessel and digested at room temperature overnight. An additional $5 \mathrm{~mL}$ of $67-70 \% \mathrm{HNO}_{3}$ was then added and the vessels were sealed and digested in the microwave according to the USEPA Method 3051A (USEPA 2007). The temperature of each vessel was preheated to $130^{\circ} \mathrm{C}$ in three minutes. The temperature was then ramped from $130^{\circ} \mathrm{C}$ to $175^{\circ} \mathrm{C}$ in two minutes and 30 seconds. Finally the temperature was ramped from $175^{\circ} \mathrm{C}$ to $180^{\circ} \mathrm{C}$ in four minutes and 30 seconds. Eight dust samples and one blank were digested in each sample batch. After digestion, half of the solution volume (approximately $5 \mathrm{~mL}$ ) was evaporated by heating on a hot plate (Fig. 3). Then $2.5 \mathrm{~mL}$ of $4 \%$ $\mathrm{H}_{3} \mathrm{BO}_{3}$ (99.999\% trace metals basis, Aldrich) was added to complex the remaining HF. The 
digestate was made up to $50 \mathrm{~mL}$ with Milli-Q water and stored in plastic bottles for analysis using inductively coupled plasma-atomic emission spectroscopy (ICP-AES) and cold vapor atomic fluorescent spectroscopy (CVAFS).

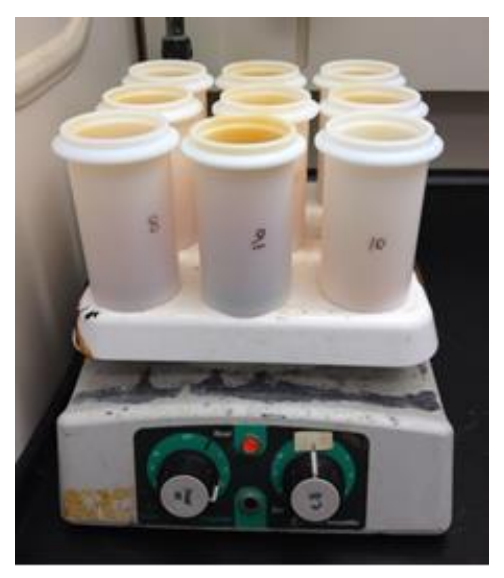

Fig. 3. Setup for acid evaporation using a hot plate

\subsubsection{Metal analysis using ICP-AES:}

$\mathrm{Ba}, \mathrm{Cd}, \mathrm{Cr}, \mathrm{Cu}, \mathrm{Mn}, \mathrm{Ni}, \mathrm{Pb}$, and $\mathrm{Zn}$ were analyzed by ICP-AES (Spectro Analytical Instruments, Model Spectroflame, Type FCPEA83F). Operation conditions of the ICP-AES are shown in Table A-1, the Appendix. Before analysis of dust samples, ICP-AES was calibrated using five multi-element standard solutions. These standard solutions were prepared from individual standard solutions having concentrations of $10000 \mu \mathrm{g} \mathrm{mL}^{-1}$ (Ultra Scientific, item numbers: IAA-056, IAA-048, IAA-024, ICP-129, IAA-026, IAA-082, and IAA-030 for Ba, Cd, $\mathrm{Cr}, \mathrm{Cu}, \mathrm{Mn}, \mathrm{Ni}, \mathrm{Pb}$, and $\mathrm{Zn}$, respectively). The five multi-element standard solutions were prepared to build up the calibration curves. The first multi-element standard solution contained 
$0.005 \mathrm{mg} \mathrm{L}^{-1} \mathrm{Cd}, 0.1 \mathrm{mg} \mathrm{L}^{-1} \mathrm{Cr}, \mathrm{Cu}, \mathrm{Mn}$, and $\mathrm{Ni}$ and $0.3 \mathrm{mg} \mathrm{L}^{-1} \mathrm{Ba}, \mathrm{Pb}$, and $\mathrm{Zn}$. The second multi-element standard solution contained $0.01 \mathrm{mg} \mathrm{L}^{-1} \mathrm{Cd}, 0.2 \mathrm{mg} \mathrm{L}^{-1} \mathrm{Cr}, \mathrm{Cu}, \mathrm{Mn}$, and $\mathrm{Ni}$, and $0.6 \mathrm{mg} \mathrm{L}^{-1} \mathrm{Ba}, \mathrm{Pb}$, and $\mathrm{Zn}$. The third multi-element standard solution contained $0.05 \mathrm{mg} \mathrm{L}^{-1} \mathrm{Cd}$, $1 \mathrm{mg} \mathrm{L}^{-1} \mathrm{Cr}, \mathrm{Cu}, \mathrm{Mn}$, and $\mathrm{Ni}$, and $3 \mathrm{mg} \mathrm{L}^{-1} \mathrm{Ba}, \mathrm{Pb}$, and $\mathrm{Zn}$. The fourth multi-element standard solution contained $0.1 \mathrm{mg} \mathrm{L}^{-1} \mathrm{Cd}, 2 \mathrm{mg} \mathrm{L}^{-1} \mathrm{Cr}, \mathrm{Cu}, \mathrm{Mn}$, and $\mathrm{Ni}$, and $6 \mathrm{mg} \mathrm{L}^{-1} \mathrm{Ba}, \mathrm{Pb}$, and $\mathrm{Zn}$. The last multi-element standard solution contained $0.15 \mathrm{mg} \mathrm{L}^{-1} \mathrm{Cd}, 3 \mathrm{mg} \mathrm{L}^{-1} \mathrm{Cr}, \mathrm{Cu}, \mathrm{Mn}, \mathrm{Ni}$, and $9 \mathrm{mg} \mathrm{L}^{-1} \mathrm{Ba}, \mathrm{Pb}$, and $\mathrm{Zn}$. Three batches of these multi-element standard solutions were prepared and digested in the same manner as mentioned for the dust samples. The average of the three batches was used to build up the calibration curves and the coefficient of determination $\left(\mathrm{R}^{2}\right)$ values were $\geq 0.9986$ (Fig. 4). The concentrations $\left(\mathrm{mg} \mathrm{kg}^{-1}\right)$ of heavy metals in the dust samples were calculated from the following equation:

Sample concentration $($ dry weight, $\mathrm{mg} / \mathrm{kg})=\mathrm{C} \times \mathrm{V} \times \mathrm{D} / \mathrm{W} \ldots \ldots \ldots \ldots \ldots 1$

where $\mathrm{C}$ is the digest concentration $\left(\mathrm{mg} \mathrm{L}^{-1}\right), \mathrm{V}$ is the final volume of the digestate $(\mathrm{L}), \mathrm{D}$ is the dilution factor, and $\mathrm{W}$ is the weight of dried sample $(\mathrm{kg})$. 

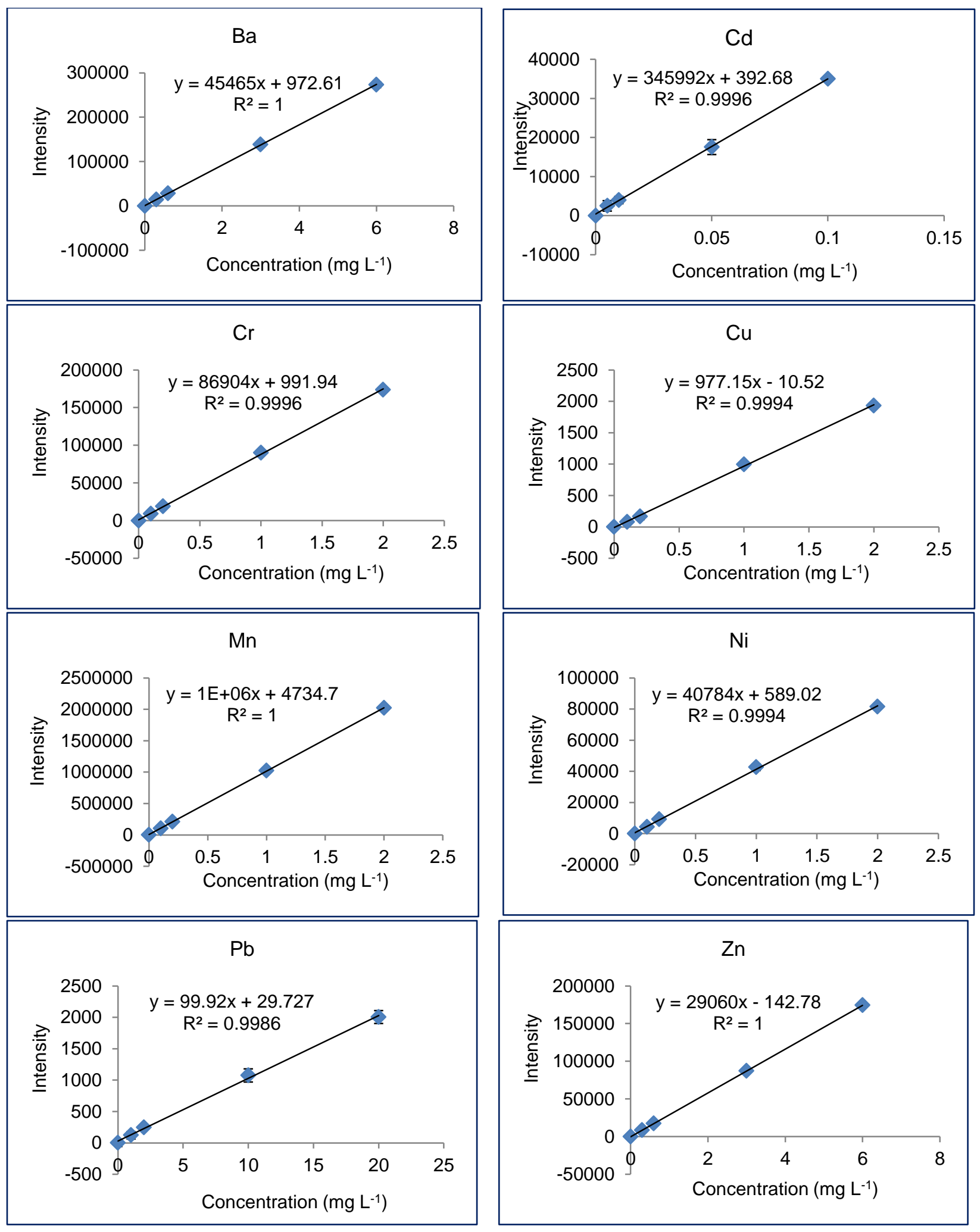

Fig. 4. Clibration curves for heavy metal analysis using ICP-AES. 


\subsubsection{Hg analysis using CVAFS:}

\subsubsection{Preparation of reagents:}

Stannous chloride $\left(\mathrm{SnCl}_{2}\right)$ : In a $50 \mathrm{~mL}$ volumetric flask, $10 \mathrm{~g}$ of $\mathrm{SnCl}_{2} \cdot 2 \mathrm{H}_{2} \mathrm{O}$ (ACS reagent, EMD) was dissolved $5 \mathrm{~mL}$ 32-35\% $\mathrm{HCl}$ (PlasmaPure Plus, SCP Science) and then the volume was brought to the mark using Milli-Q water. The $\mathrm{SnCl}_{2}$ solution was purged for 1 hour with $\mathrm{Hg}$ free nitrogen $\left(\mathrm{N}_{2}\right)$ gas at $500 \mathrm{~mL} \mathrm{~min}{ }^{-1}$. The solution was prepared fresh monthly and stored in the refrigerator when not in use.

Hydroxylamine hydrochloride $\left(\mathrm{HN}_{2} \mathrm{OH} . \mathrm{HCl}\right): 15 \mathrm{~g}$ of $\mathrm{NH}_{2} \mathrm{OH} . \mathrm{HCl}$ (ACS reagent, J.T. Baker) was dissolved in Milli-Q water and brought to $50 \mathrm{~mL}$. This solution was purified by the addition of $50 \mu \mathrm{L}$ of $\mathrm{SnCl}_{2}$ and purged for 1 hour with $\mathrm{Hg}$-free $\mathrm{N}_{2}$ gas at $500 \mathrm{~mL} \mathrm{~min}^{-1}$. The solution was prepared fresh monthly and stored in the refrigerator when not in use.

Bromine monochloride ( $\mathrm{BrCl}$ ): Inside a fume hood, $1.1 \mathrm{~g}$ of $\mathrm{KBr}$ (ACS reagent, EM Science) was dissolved in $100 \mathrm{~mL}$ of $32-35 \% \mathrm{HCl}$. The solution was kept well mixed using a magnetic stir bar for approximately 1 hour. Then $1.5 \mathrm{~g}$ of $\mathrm{KBrO}_{3}$ (ACS reagent, J.T. Baker) was added slowly to the solution while stirring. After all $\mathrm{KBrO}_{3}$ was added, the container was loosely capped and the solution was stirred for another hour before tightening the lid.

\subsubsection{Determination of total $\mathrm{Hg}$ :}

The analysis of total Hg (THg) was based on the USEPA Method 1631B (USEPA 1999) and Appendix to Method 1631 (USEPA 2001). Briefly, $2 \mathrm{~mL}$ of the digestate of the dust sample (Section 2.3.1) was added to a bubbler containing $100 \mathrm{~mL}$ of Milli-Q water and $0.5 \mathrm{~mL}$ of $\mathrm{BrCl}$ 
solution. After 1 hour, the excess of $\mathrm{BrCl}$ was removed by addition of $0.25 \mathrm{~mL}$ of $\mathrm{NH}_{2} \mathrm{OH} . \mathrm{HCl}$. After 5 minutes, $0.5 \mathrm{~mL}$ of $\mathrm{SnCl}_{2}$ solution was added to reduce $\mathrm{Hg}^{2+}$ into elemental $\mathrm{Hg}\left(\mathrm{Hg}^{0}\right)$. The reduced $\mathrm{Hg}$ was then purged with $\mathrm{Hg}$-free $\mathrm{N}_{2}$ gas at $350 \mathrm{~mL} \mathrm{~min}^{-1}$ for 20 minutes and collected onto a gold trap (Fig. 5).

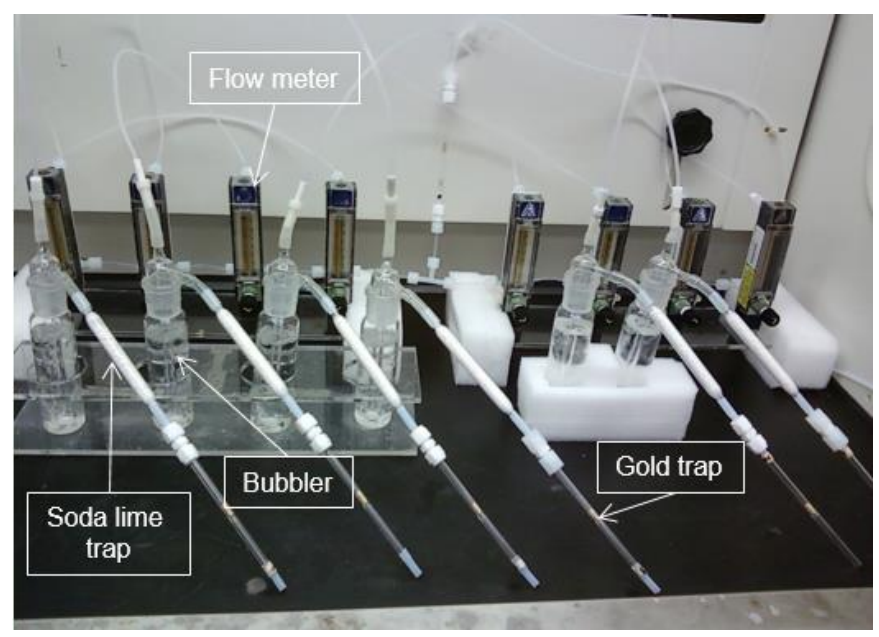

Fig. 5. Bubbler setup for purging and trapping of the $\mathrm{Hg}^{0}$.

The gold trap (i.e., the sample trap) then was heated up to $450^{\circ} \mathrm{C}$ for three minutes in a stream of argon (Ar) gas to desorb the $\mathrm{Hg}$ from the sample trap onto another gold trap (i.e., the analytical trap). Finally, the analytical trap (Fig. 6) was heated up to $450^{\circ} \mathrm{C}$ for three minutes and the released $\mathrm{Hg}$ was fed into CVAFS (Brooks Rand LTD., Seattle Washington, USA) for detection and quantification. The Mercury Guru 2.2 software was used to integrate the peak area of the detected signals. 


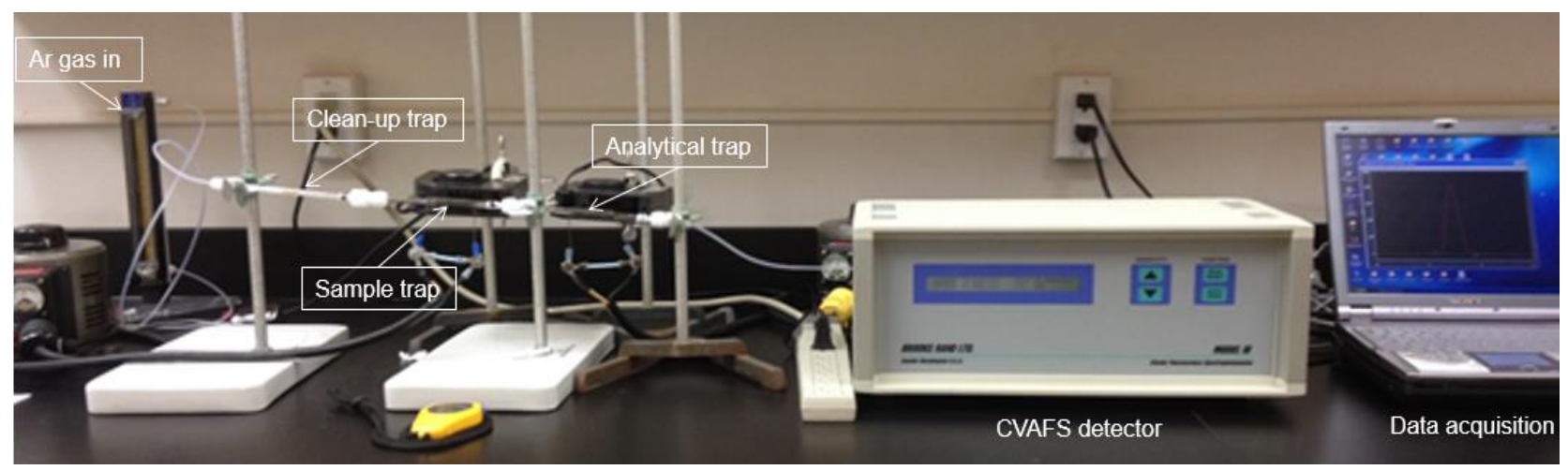

Fig. 6. Apparatus setup for CVAFS analysis of the THg.

Five non-zero points and the results of analysis of three bubbler blanks were used for the calibration. The standard solutions were prepared from the stock $\mathrm{Hg}$ standard $10000 \mu \mathrm{g} \mathrm{mL}{ }^{-1}$ (ICP-180, Ultra Scientific). The concentrations of the first, second, third, fourth, and fifth standard solutions were $0.5 \mathrm{ng} \mathrm{L}^{-1}, 5.0 \mathrm{ng} \mathrm{L}^{-1}, 25 \mathrm{ng} \mathrm{L}^{-1}, 50 \mathrm{ng} \mathrm{L}^{-1}$, and $100 \mathrm{ng} \mathrm{L}^{-1}$, respectively. The standard solutions were digested and analyzed. The calibration factor $\left(\mathrm{CF}_{\mathrm{x}}\right)$ for $\mathrm{Hg}$ in each of the five standards was calculated using the following equation:

$$
\mathrm{CF}_{\mathrm{x}}=\left(\mathrm{A}_{\mathrm{x}}-\mathrm{A}_{\mathrm{B}}\right) / \mathrm{C}_{\mathrm{x}}
$$

where $A_{x}$ is the peak area for $\mathrm{Hg}$ in the standard, $A_{B}$ is the mean peak area for $\mathrm{Hg}$ in the bubbler blanks, and $\mathrm{C}_{\mathrm{x}}$ is the concentration of the standard analyzed $\left(\mathrm{ng} \mathrm{\textrm {L } ^ { - 1 }}\right)$. Then the mean calibration factor $\left(\mathrm{CF}_{\mathrm{m}}\right)$, the standard deviation of the calibration factor (SD), and the relative standard deviation $(\mathrm{RSD})$ of the calibration factor $\left(\mathrm{RSD}=100 \times \mathrm{SD} / \mathrm{CF}_{\mathrm{m}}\right)$ were calculated. The RSD of the calibration factor was $12 \%$ and the average of the percent recoveries of the lowest standard was $77 \%$, which were in the EPA recommended range (i.e., RSD is $\leq 15 \%$ and the recovery of the lowest standard is 75-125\%) stated in the USEPA Method 1631 and Appendix to Method 
1631 (Table A-2, the Appendix). To calculate the concentration of $\mathrm{Hg}$ in dust samples, equation 3 below was used.

$$
\mathrm{C}_{\mathrm{Hg}}=\left(\mathrm{A}_{\mathrm{s}}-\mathrm{A}_{\mathrm{B}}\right) \times \mathrm{V} \times 0.1 /\left(\mathrm{CF}_{\mathrm{m}} \times \mathrm{v} \times \mathrm{w}\right)
$$

where $\mathrm{C}_{\mathrm{Hg}}$ is the concentration of $\mathrm{Hg}$ in the dust sample (ng $\mathrm{g}^{-1}$, dry weight), $\mathrm{A}_{\mathrm{s}}$ is the peak area for $\mathrm{Hg}$ in the digestate, $\mathrm{A}_{\mathrm{B}}$ is the peak area for the average of the bubbler blanks, $\mathrm{V}$ is the volume of the digestate $(\mathrm{mL})$, which was $50 \mathrm{~mL}, 0.1$ is the volume in the bubbler $(\mathrm{L}), \mathrm{CF}_{\mathrm{m}}$ is the mean value of the calibration factors from the calibration, $\mathrm{v}$ is the digestate volume analyzed $(\mathrm{mL})$, and $\mathrm{w}$ is the dry sample weight $(\mathrm{g})$.

\subsection{Quality control (QC):}

\subsubsection{Blanks:}

Method blanks were used to evaluate external metal concentration introduced by analytical procedures. Before sample analysis, 30 blanks were digested and analyzed and the results are shown in Fig. A-1, the Appendix. During the sample analysis by ICP-AES and CVAFS, one method blank was included in each sample batch (up to eight samples). All blanks were digested and analyzed using the same analytical procedures but without dust samples. The concentrations of metals in the samples were calculated after blank correction. 


\subsubsection{Method detection limit:}

Thirty blanks were digested and analyzed by ICP-AES to calculate the method detection limit (MDL) at the respective wavelengths selected for each metal. The standard deviation (SD) of the blanks was used to calculate the MDL using equation 4 according to the USEPA method “40 CFR Part 136, Appendix B”.

$$
\mathrm{MDL}=t \times \mathrm{SD}
$$

where $t$ is the Student's $t$ value at a 99\% confidence level and SD is the standard deviation of the replicates. The Student's $t$ value was 2.46 at a $99 \%$ confidence level for 29 degrees of freedom (n-1). The method detection limits were calculated to be $5.75 \mathrm{mg} \mathrm{kg}^{-1}$ for $\mathrm{Ba}, 0.42 \mathrm{mg} \mathrm{kg}^{-1}$ for $\mathrm{Cd}, 0.74 \mathrm{mg} \mathrm{kg}^{-1}$ for $\mathrm{Cr}, 28.3 \mathrm{mg} \mathrm{kg}^{-1}$ for $\mathrm{Cu}, 0.13 \mathrm{mg} \mathrm{kg}^{-1}$ for $\mathrm{Mn}, 1.44 \mathrm{mg} \mathrm{kg}^{-1}$ for $\mathrm{Ni}, 13.0 \mathrm{mg}$ $\mathrm{kg}^{-1}$ for $\mathrm{Pb}$, and $2.59 \mathrm{mg} \mathrm{kg}^{-1}$ for $\mathrm{Zn}$.

To calculate the method detection limit of $\mathrm{Hg}$, seven replicates having concentration of $2.5 \mathrm{ng} \mathrm{\textrm {L } ^ { - 1 }}$ were digested and analyzed using CVAFS. The standard deviation of the seven replicates was used to calculate the MDL using the equation 4. The Student's $t$ value was 3.14 at a $99 \%$ confidence level for 6 degrees of freedom (n-1). The MDL of $\mathrm{Hg}$ was calculated to be $0.49 \mathrm{ng} \mathrm{g}^{-1}$ (0.00049 $\mathrm{mg} \mathrm{kg}^{-1}$; Table A-3, the Appendix).

\subsubsection{Method validation:}

The accuracy of the methods was evaluated by analysis of a Standard Reference Material (SRM 2584, Trace Element in Indoor Dust) obtained from the National Institute of Standards 
and Technology (NIST). The SRM 2584 sample was digested and analyzed (in triplicate) in the same manner as the dust samples. The agreement between the certified values and measured values for each metal was satisfactory (using $t$-test) with the recoveries being between $90 \%$ and 103\%. The results for the SRM analysis are given in Table 1.

Table 1. Recovery and precision for the determination of metals in SRM 2584 (NIST, Trace Element in Indoor Dust) using ICP-AES.

\begin{tabular}{|c|c|c|c|c|}
\hline Element & $\begin{array}{r}\text { Measured value } \\
\left(\mathrm{mg} \mathrm{kg}^{-1}\right)^{\mathrm{a}}\end{array}$ & $\mathrm{RSD} \%{ }^{b}$ & $\begin{array}{r}\text { Certified value } \\
\left(\mathrm{mg} \mathrm{kg}^{-1}\right)\end{array}$ & Recovery $\%^{\mathrm{c}}$ \\
\hline $\mathrm{Cd}$ & $10.4 \pm 0.5$ & 5 & $10.0 \pm 1.1$ & 104 \\
\hline $\mathrm{Cr}$ & $121.6 \pm 12.8$ & 10 & $135.0 \pm 9.1$ & 90 \\
\hline $\mathrm{Hg}^{\mathrm{d}}$ & $4.98 \pm 0.24$ & 5 & $5.20 \pm 0.24$ & 96 \\
\hline $\mathrm{Pb}$ & $10024 \pm 263$ & 3 & $9761 \pm 67$ & 103 \\
\hline $\mathrm{Zn}$ & $2460 \pm 77$ & 3 & $2580 \pm 150$ & 95 \\
\hline $\mathrm{Ba}$ & $1228 \pm 31$ & 3 & 1300 & 94 \\
\hline $\mathrm{Cu}$ & $299 \pm 14$ & 5 & 320 & 93 \\
\hline Mn & $360 \pm 9$ & 2 & 370 & 97 \\
\hline $\mathrm{Ni}$ & $87 \pm 2$ & 2 & 90 & 97 \\
\hline
\end{tabular}

${ }^{a}$ Measured value is the mean concentration for three replicates \pm standard deviation (SD)

${ }^{\mathrm{b}} \mathrm{RSD}$ is the relative standard deviation for three replicate $=(\mathrm{SD} /$ mean $) \times 100$

${ }^{\mathrm{c}}$ Recovery $=($ measured value $/$ certified value $) \times 100$

${ }^{\mathrm{d}} \mathrm{Hg}$ was analyzed by CVAFS 
In order to determine the analytical precision, a triplicate of the SRM 2584 was analyzed and the RSD was 2-10\% (Table 1). Also, nine selected dust samples were analyzed in triplicate and the RSD values were $1-9 \%$ for $\mathrm{Ba}, 2-18 \%$ for $\mathrm{Cd}, 1-5 \%$ for $\mathrm{Cr}, 6-18 \%$ for $\mathrm{Cu}, 2-8 \%$ for $\mathrm{Hg}$, $1-9 \%$ for $\mathrm{Mn}, 1-9 \%$ for $\mathrm{Ni}, 2-20 \%$ for $\mathrm{Pb}$, and $2-16 \%$ for $\mathrm{Zn}$.

The initial precision and recovery (IPR) solution with a concentration of $5 \mathrm{ng} \mathrm{L}^{-1}$ was analyzed to demonstrate the ability of the CVAFS to provide acceptable precision and recovery. The average percent recovery and the RSD for the four replicates of the IPR solution were calculated to be $104 \%$ and $4 \%$, respectively (Table A-4, the Appendix). The results met the QC acceptance criteria (i.e., IPR recovery is $75-125 \%$ and IPR precision is $<20 \%$ RSD) of the USEPA Method 1631B and Appendix to Method 1631.

\subsubsection{Calibration Verification:}

For ICP-AES analysis, a multi-element standard solution with a concentration of $1.0 \mathrm{mg}$

$\mathrm{L}^{-1}$ for each metal was used prior to and after the analysis of every 20 samples to verify calibration of the instrument. The percent recoveries for each metal were $100-108 \%$ for $\mathrm{Ba}, 107$ $112 \%$ for $\mathrm{Cd}, 89-99 \%$ for $\mathrm{Cr}, 102-113 \%$ for $\mathrm{Cu}, 92-100 \%$ for $\mathrm{Mn}, 90-100 \%$ for $\mathrm{Ni}, 98-110 \%$ for $\mathrm{Pb}$, and $90-96 \%$ for $\mathrm{Zn}$. For CVAFS analysis, a standard solution of $\mathrm{Hg}$ with a concentration of $40 \mathrm{ng} \mathrm{L}^{-1}$ was used prior to and after the analysis of every eight samples. The percent recovery of this standard solution was calculated to be $98-122 \%$, which was in the EPA range (i.e., 77-123\%) according to the USEPA Method 1631B and Appendix to Method 1631. 


\subsection{Statistical analysis:}

The data of metal concentrations in the indoor dusts showed log-normal distributions (Fig. A-2, the Appendix). Therefore, the data were log-transformed prior to performing the statistical tests, including $t$-test, analysis of variance (ANOVA), and Pearson's correlation analysis. The comparison between the mean concentrations of metals in household dusts collected in the winter of 2012 and 2013 was performed using $t$-test (the statistical functions in Microsoft Excel, 2013). Also, the $t$-test was used to compare between the certified values of metal concentrations in the SRM and the observed values. One-way ANOVA (using the Statistical Analysis Software; SAS 10.2) was conducted for multi-comparison among the mean concentrations of the metals in different indoor dusts (i.e., household, office, classroom, and laboratory dusts). The correlations between metal concentrations in each indoor environment were performed by the Pearson's correlation analysis (using the Statistical Package for Social Science; IBM SPSS Statistics 21). 


\section{RESULTS AND DISCUSSION:}

\subsection{Heavy metal concentrations in household dusts:}

Household settled dusts collected from 67 residences during the winter of 2012 and 2013 within the Greater Toronto Area (GTA) were analyzed for the total content of heavy metals. The concentrations of the metals studied are presented in Table 2. All values were based on dry weight. For household dusts collected in the winter of 2012, Zn showed the highest arithmetic mean concentration (419 $\left.\mathrm{m} \mathrm{kg}^{-1}\right)$ followed by $\mathrm{Cu}(156 \mathrm{mg} \mathrm{kg}-1), \mathrm{Ba}\left(102 \mathrm{mg} \mathrm{kg}^{-1}\right), \mathrm{Pb}(87.6 \mathrm{mg}$ $\left.\mathrm{kg}^{-1}\right), \mathrm{Mn}\left(63.9 \mathrm{mg} \mathrm{kg}^{-1}\right), \mathrm{Cr}\left(52.7 \mathrm{mg} \mathrm{kg}^{-1}\right), \mathrm{Ni}\left(27.6 \mathrm{mg} \mathrm{kg}^{-1}\right), \mathrm{Cd}\left(4.01 \mathrm{mg} \mathrm{kg}^{-1}\right)$, and $\mathrm{Hg}(0.66$ $\mathrm{mg} \mathrm{kg}^{-1}$; Table 2). Zn concentration (1345 $\mathrm{mg} \mathrm{kg}^{-1}$ ) was also the highest in household dusts collected in the winter of 2013 followed by $\mathrm{Cu}\left(248 \mathrm{mg} \mathrm{kg}^{-1}\right), \mathrm{Mn}\left(136 \mathrm{mg} \mathrm{kg}^{-1}\right), \mathrm{Ba}(111 \mathrm{mg}$ $\left.\mathrm{kg}^{-1}\right), \mathrm{Cr}\left(109 \mathrm{mg} \mathrm{kg}^{-1}\right), \mathrm{Pb}\left(83.8 \mathrm{mg} \mathrm{kg}^{-1}\right), \mathrm{Ni}\left(38.4 \mathrm{mg} \mathrm{kg}^{-1}\right), \mathrm{Cd}\left(2.88 \mathrm{mg} \mathrm{kg}^{-1}\right)$, and $\mathrm{Hg}(1.01$ $\mathrm{mg} \mathrm{kg}^{-1}$; Table 2). For all results (winter of 2012 and 2013), the same trend was observed in which $\mathrm{Zn}$ was the highest concentration $\left(778 \mathrm{mg} \mathrm{kg}^{-1}\right)$ followed by $\mathrm{Cu}\left(191 \mathrm{mg} \mathrm{kg}^{-1}\right), \mathrm{Ba}(106$ mg kg-1), Mn (92.1 $\left.\mathrm{mg} \mathrm{kg}^{-1}\right), \mathrm{Pb}\left(86.3 \mathrm{mg} \mathrm{kg}^{-1}\right), \mathrm{Cr}\left(74.7 \mathrm{mg} \mathrm{kg}^{-1}\right), \mathrm{Ni}\left(31.8 \mathrm{mg} \mathrm{kg}^{-1}\right), \mathrm{Cd}(3.73$ $\left.\mathrm{mg} \mathrm{kg}{ }^{-1}\right)$, and $\mathrm{Hg}\left(0.80 \mathrm{mg} \mathrm{kg}^{-1}\right.$; Table 2). The $t$ test was performed to compare the metal concentrations in household dusts collected in the winter of 2012 and 2013. The results showed that there were statistically no significant differences $(p<0.05)$ between metal concentrations in household dusts collected in the winter of 2012 and 2013 except that Mn and Zn concentrations were significantly higher $(p<0.05)$ in the winter of 2013 than those in the winter of 2012 (Fig. 7). 
Table 2. Total metal concentrations ( $\mathrm{mg} \mathrm{kg}^{-1}$, dry weight) in the household dust samples collected in GTA, Canada.

\begin{tabular}{|c|c|c|c|c|c|c|c|c|c|c|}
\hline $\begin{array}{l}\text { Sampling } \\
\text { Period }\end{array}$ & & $\mathrm{Ba}$ & $\mathrm{Cd}$ & $\mathrm{Cr}$ & $\mathrm{Cu}$ & $\mathrm{Hg}$ & $\mathrm{Mn}$ & $\mathrm{Ni}$ & $\mathrm{Pb}$ & $\overline{\mathrm{Zn}}$ \\
\hline \multirow{6}{*}{$\begin{array}{l}\text { Winter } 2012 \\
(n=41)\end{array}$} & AM & 102 & 4.01 & 52.7 & 156 & 0.66 & 63.9 & 27.6 & 87.6 & 419 \\
\hline & SD & 111 & 9.49 & 50.4 & 119 & 1.29 & 43.8 & 17.5 & 186 & 308 \\
\hline & GM & 65.0 & 2.03 & 42.8 & 122 & 0.33 & 49.0 & 22.8 & 38.3 & 327 \\
\hline & Median & 68.8 & 1.69 & 40.6 & 125 & 0.37 & 58.4 & 22.6 & 36.9 & 359 \\
\hline & Min & 1.52 & 0.23 & 8.90 & 21.8 & 0.01 & 5.57 & 5.04 & 3.09 & 67.9 \\
\hline & Max & 525 & 60.3 & 336 & 642 & 8.02 & 168 & 78.2 & 1141 & 1345 \\
\hline \multirow{6}{*}{$\begin{array}{l}\text { Winter } 2013 \\
(n=26)\end{array}$} & $\mathrm{AM}$ & 111 & 2.88 & 109 & 248 & 1.01 & 136 & 38.4 & 83.8 & 1345 \\
\hline & SD & 118 & 3.18 & 284 & 263 & 1.93 & 207 & 52.9 & 138 & 2989 \\
\hline & GM & 61.9 & 1.47 & 51.8 & 175 & 0.51 & 77.8 & 21.7 & 36.8 & 569 \\
\hline & Median & 72.1 & 1.61 & 43.6 & 159 & 0.46 & 78.6 & 24.3 & 35.3 & 480 \\
\hline & Min & 1.81 & 0.10 & 9.46 & 23.8 & 0.07 & 7.81 & 2.59 & 5.18 & 115 \\
\hline & Max & 462 & 10.9 & 1490 & 1249 & 10.1 & 1076 & 261 & 622 & 14684 \\
\hline \multirow{6}{*}{$\begin{array}{l}\text { All results } \\
(n=67)\end{array}$} & $\mathrm{AM}$ & 106 & 3.73 & 74.7 & 191 & 0.80 & 92.1 & 31.8 & 86.3 & 778 \\
\hline & SD & 113 & 8.37 & 181 & 190 & 1.57 & 137 & 35.7 & 169 & 1910 \\
\hline & GM & 63.7 & 1.87 & 46.1 & 140 & 0.39 & 58.6 & 22.4 & 37.8 & 405 \\
\hline & Median & 71.4 & 1.67 & 42.5 & 136 & 0.39 & 58.5 & 23.0 & 36.1 & 386 \\
\hline & Min & 1.52 & 0.10 & 8.90 & 21.8 & 0.01 & 5.57 & 2.59 & 3.09 & 67.9 \\
\hline & Max & 525 & 60.3 & 1490 & 1249 & 10.1 & 1076 & 261 & 1141 & 14684 \\
\hline $\begin{array}{l}\text { Canadian Soil } \\
\text { Guideline }^{\mathrm{a}}\end{array}$ & & 500 & 10 & 64 & 63 & 6.6 & N/A & 50 & 140 & 200 \\
\hline
\end{tabular}




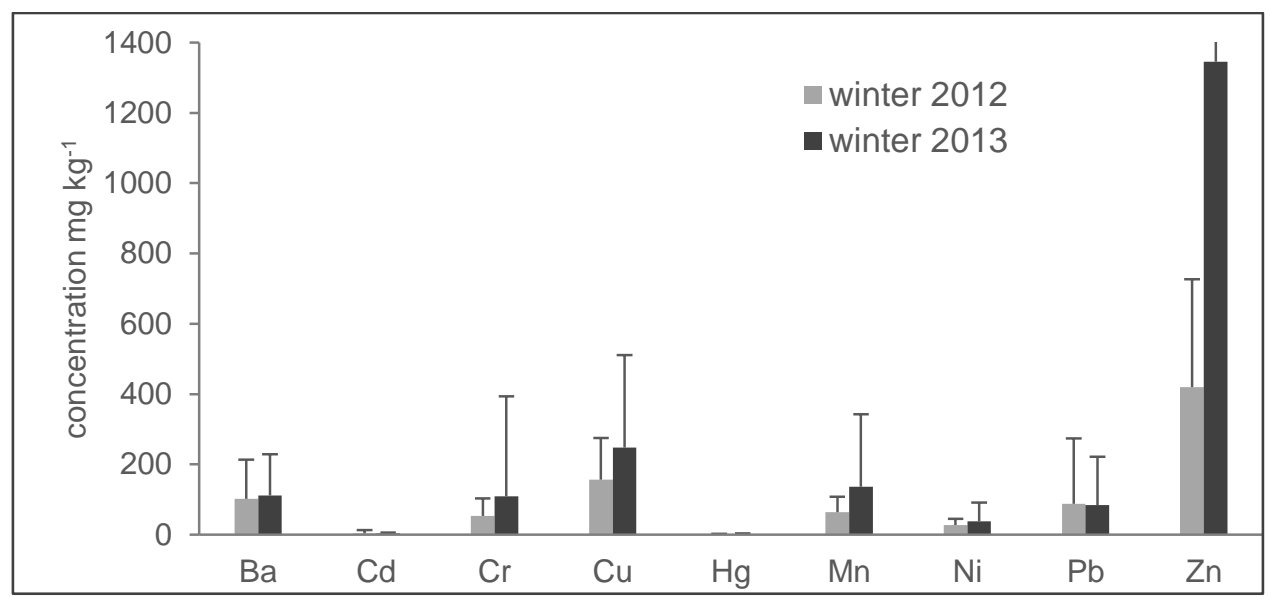

Fig. 7. Comparison of the arithmetic mean concentrations of metals in the household dusts collected in the winter of 2012 and 2013.

To the best of our knowledge, there are no guidelines for heavy metals in dusts. Therefore, in several studies heavy metal concentrations in dusts have been compared with soil guidelines for metals (Hassan 2012; Kurt-Karakus 2012; Kefeni and Okonkov 2013; Lu et al. 2014). The Canadian Soil Guideline (residential/ parkland) provided by Canadian Council of Ministers of the Environment (CCME) was used for comparison purposes. The CCME guideline values (CCME 2014) for metals in soil were listed in Table 2; CCME 2014). Looking at Table 2, it can be seen that $\mathrm{Ba}\left(106 \mathrm{mg} \mathrm{kg}^{-1}\right), \mathrm{Cd}(3.73 \mathrm{mg} \mathrm{kg}-1), \mathrm{Hg}\left(0.80 \mathrm{mg} \mathrm{kg}^{-1}\right), \mathrm{Ni}\left(31.8 \mathrm{mg} \mathrm{kg}^{-1}\right), \mathrm{Pb}$ $\left(86.3 \mathrm{mg} \mathrm{kg}^{-1}\right)$ concentrations in household dusts collected in the winter of 2012 and 2013 were lower than the CCME guideline values, whereas $\mathrm{Cr}\left(74.7 \mathrm{mg} \mathrm{kg}^{-1}\right), \mathrm{Cu}\left(191 \mathrm{mg} \mathrm{kg}^{-1}\right)$, and $\mathrm{Zn}$ (778 $\mathrm{mg} \mathrm{kg}^{-1}$ ) concentrations were higher than the acceptable levels in the CCME guideline.

The concentrations of heavy metals were plotted on the GTA map using Geographic Information System (GIS) software (Esri ArcMap 10.2) and the results are depicted in Fig. 8 to Fig. 16. Elevated levels of metal concentrations were observed and most of them located in downtown Toronto, which is characterized by higher density of traffic and population. The 
arithmetic mean concentrations of metals in downtown Toronto $(n=12)$ and the other regions of the GTA $(n=55)$ were $161 \mathrm{mg} \mathrm{kg}^{-1}$ and $93.2 \mathrm{mg} \mathrm{kg}^{-1}$ for Ba, $2.80 \mathrm{mg} \mathrm{kg}^{-1}$ and $4.00 \mathrm{mg} \mathrm{kg}^{-1}$ for $\mathrm{Cd}, 78.3 \mathrm{mg} \mathrm{kg}^{-1}$ and $73.9 \mathrm{mg} \mathrm{kg}^{-1}$ for $\mathrm{Cr}, 251 \mathrm{mg} \mathrm{kg}^{-1}$ and $177 \mathrm{mg} \mathrm{kg}^{-1}$ for $\mathrm{Cu}, 1.47 \mathrm{mg} \mathrm{kg}^{-1}$ and $0.65 \mathrm{mg} \mathrm{kg}^{-1}$ for $\mathrm{Hg}, 93.8 \mathrm{mg} \mathrm{kg}^{-1}$ and $91.7 \mathrm{mg} \mathrm{kg}^{-1}$ for $\mathrm{Mn}, 29.4 \mathrm{mg} \mathrm{kg}^{-1}$ and $32.3 \mathrm{mg} \mathrm{kg}^{-1}$ for $\mathrm{Ni}, 190 \mathrm{mg} \mathrm{kg}^{-1}$ and $64.7 \mathrm{mg} \mathrm{kg}^{-1}$ for $\mathrm{Pb}$, and $630 \mathrm{mg} \mathrm{kg}^{-1}$ and $817 \mathrm{mg} \mathrm{kg}^{-1}$ for $\mathrm{Zn}$, respectively.

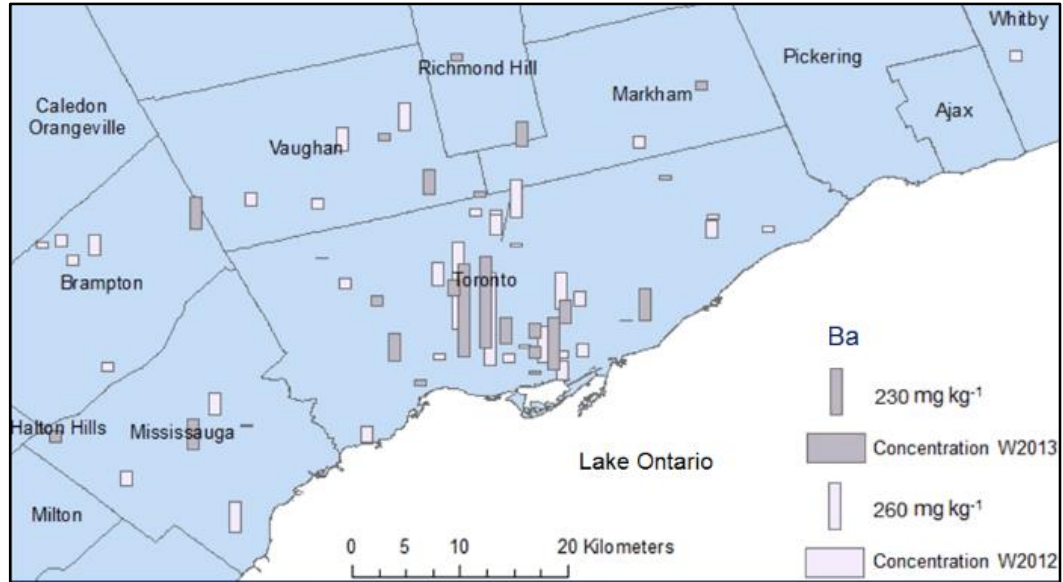

Fig. 8. Geographical distribution of Ba concentrations in the household dusts collected in the winter of 2012 and winter 2013 in GTA, Canada.

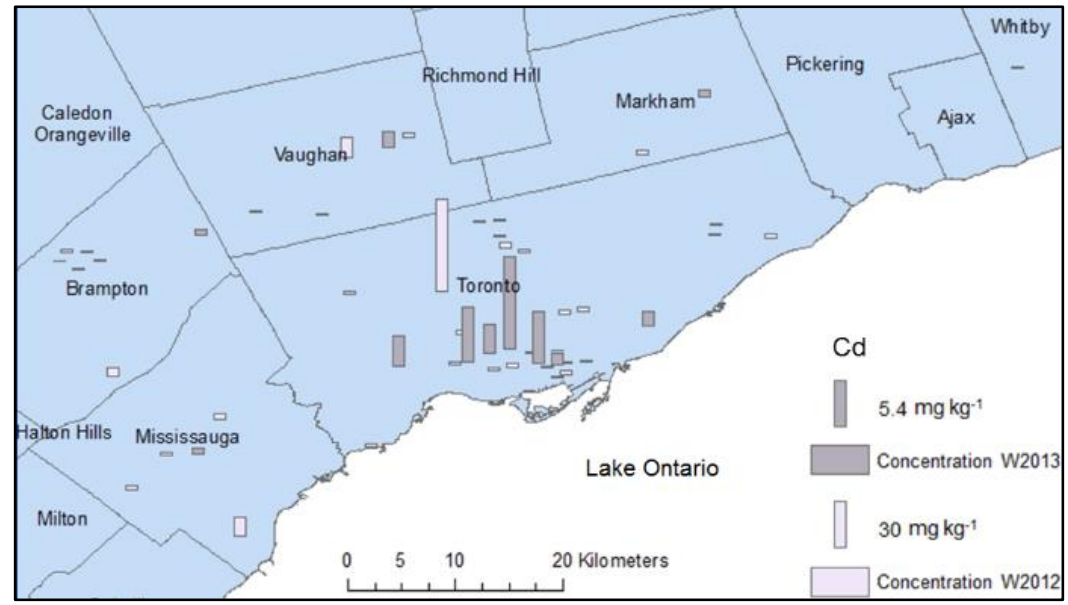

Fig. 9. Geographical distribution of Cd concentrations in the household dusts collected in the winter of 2012 and winter 2013 in GTA, Canada. 


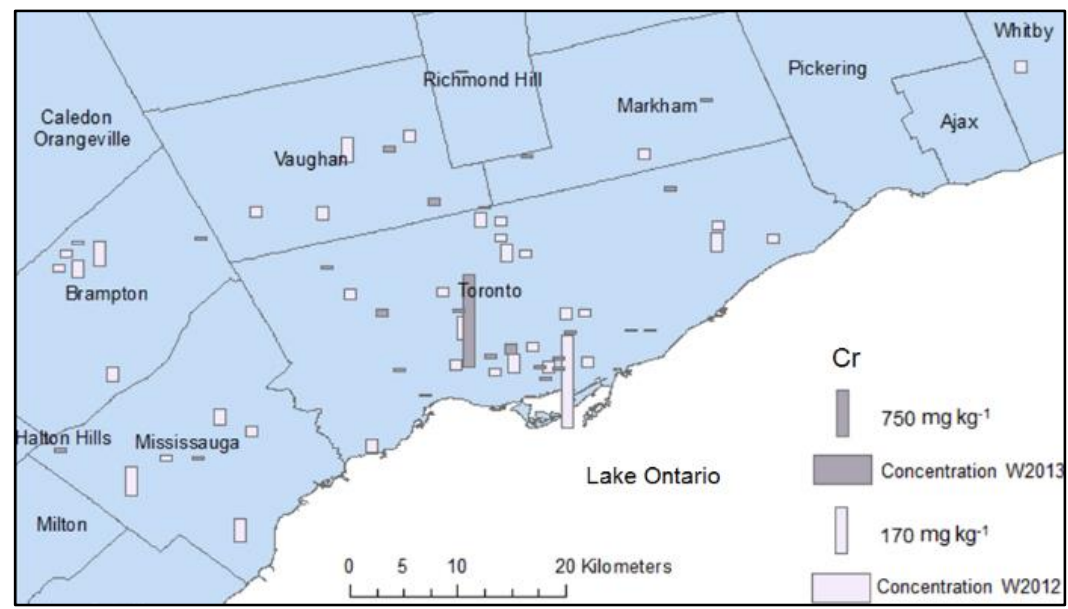

Fig. 10. Geographical distribution of $\mathrm{Cr}$ concentrations in the household dusts collected in the winter of 2012 and winter 2013 in GTA, Canada.

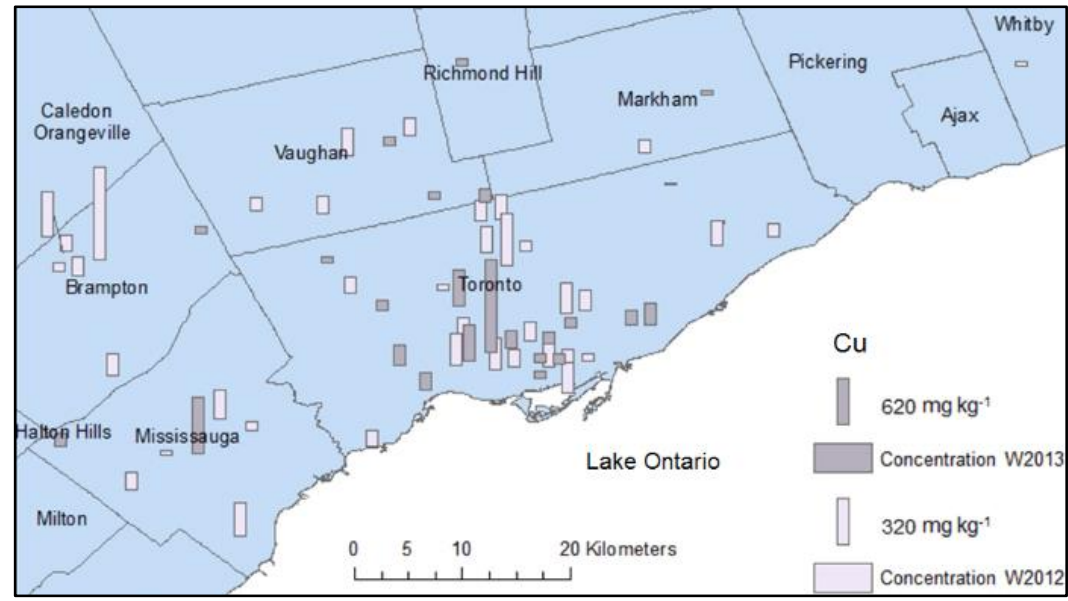

Fig. 11. Geographical distribution of $\mathrm{Cu}$ concentrations in the household dusts collected in the winter of 2012 and winter 2013 in GTA, Canada.

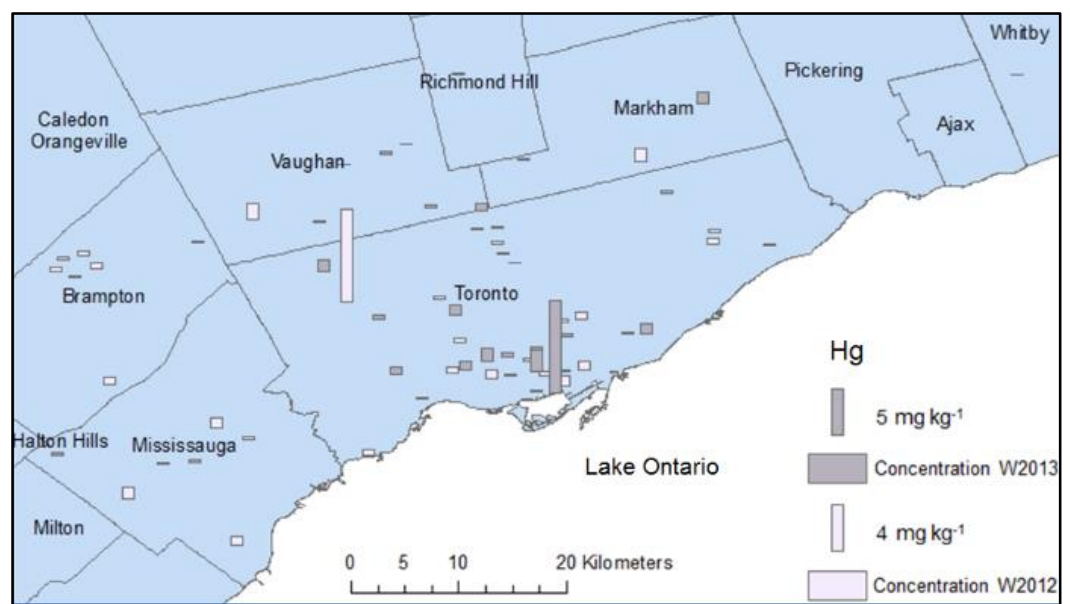

Fig. 12. Geographical distribution of $\mathrm{Hg}$ concentrations in the household dusts collected in the winter of 2012 and winter 2013 in GTA, Canada. 


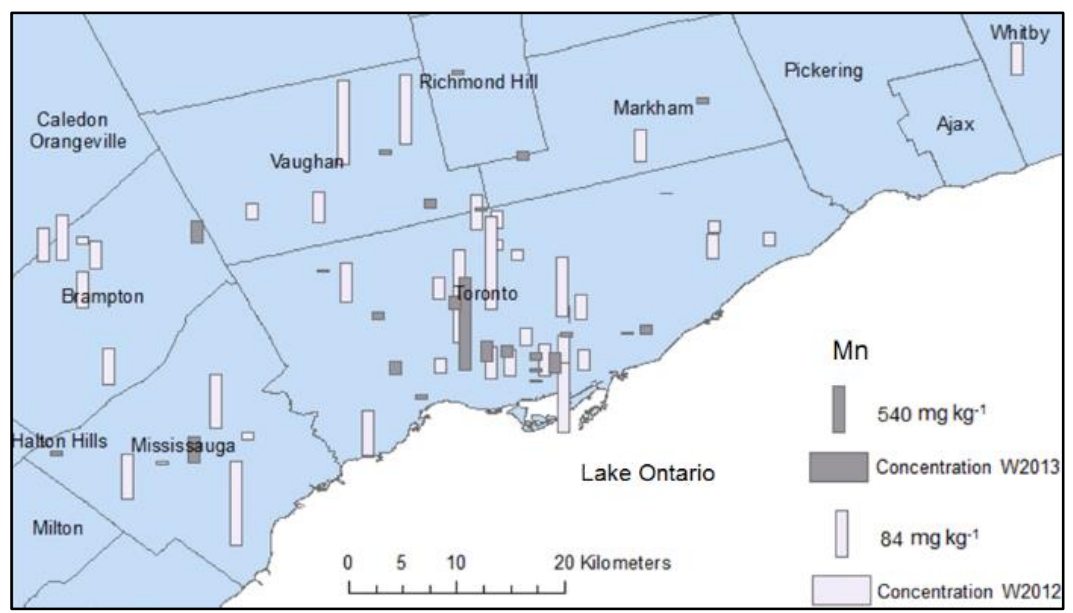

Fig. 13. Geographical distribution of Mn concentrations in the household dusts collected in the winter of 2012 and winter 2013 in GTA, Canada.

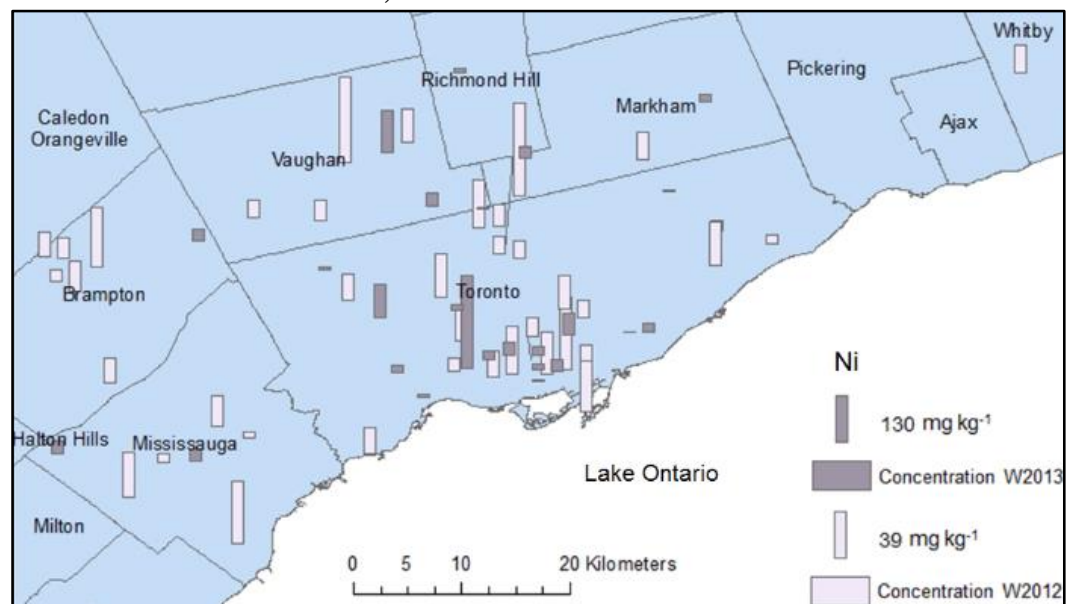

Fig. 14. Geographical distribution of Ni concentrations in the household dusts collected in the winter of 2012 and winter 2013 in GTA, Canada.

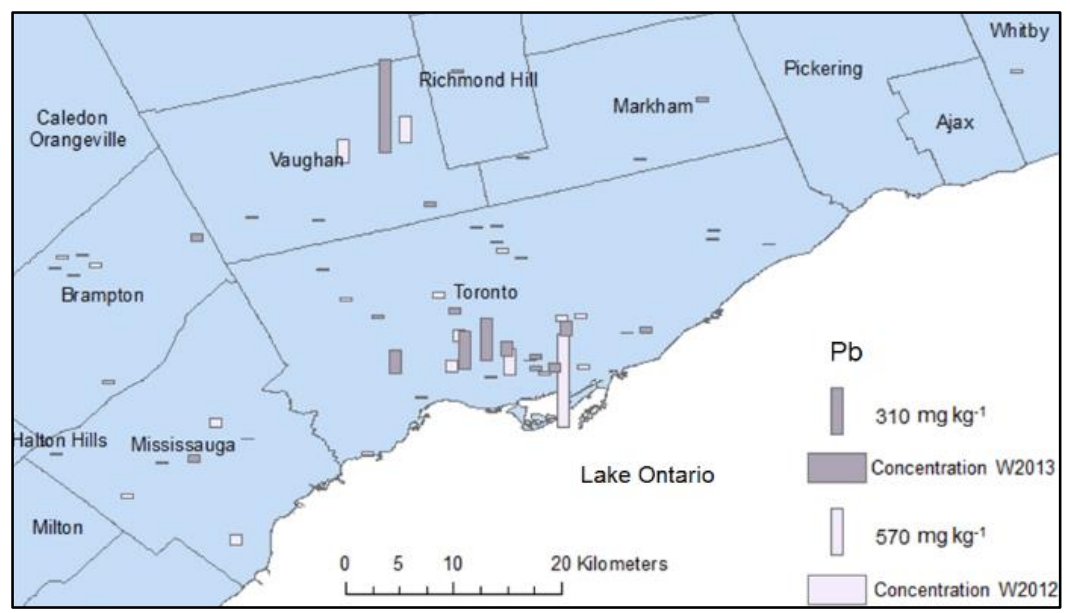

Fig. 15. Geographical distribution of $\mathrm{Pb}$ concentrations in the household dusts collected in the winter of 2012 and winter 2013 in GTA, Canada. 


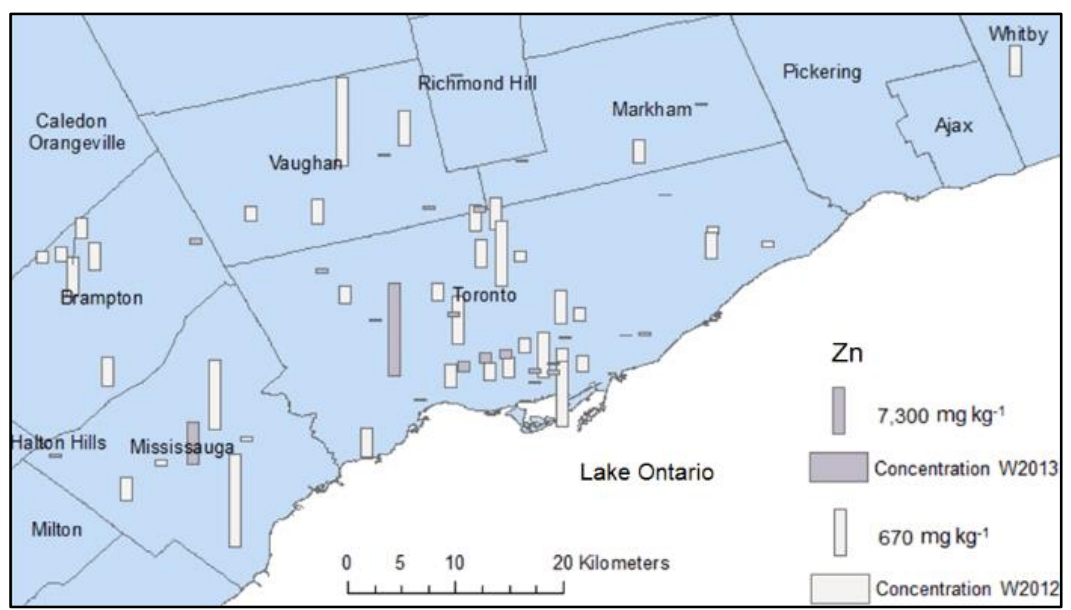

Fig. 16. Geographical distribution of Zn concentrations in the household dusts collected in the winter of 2012 and winter 2013 in GTA, Canada.

Figure 17 shows the comparison between the metal concentrations in downtown Toronto and the other regions of the GTA. Except $\mathrm{Pb}$, there were statistically no differences between metal concentrations in downtown Toronto and the other regions of the GTA. The $\mathrm{Pb}$ concentration in household dusts in downtown Toronto was significantly higher $(p<0.05)$ than the concentration in the other regions of the GTA. This could be attributed to the accumulation of $\mathrm{Pb}$ from the use of leaded gasoline and leaded paints in the past (Chattopadyay et al. 2003; Charlesworth et al. 2011).

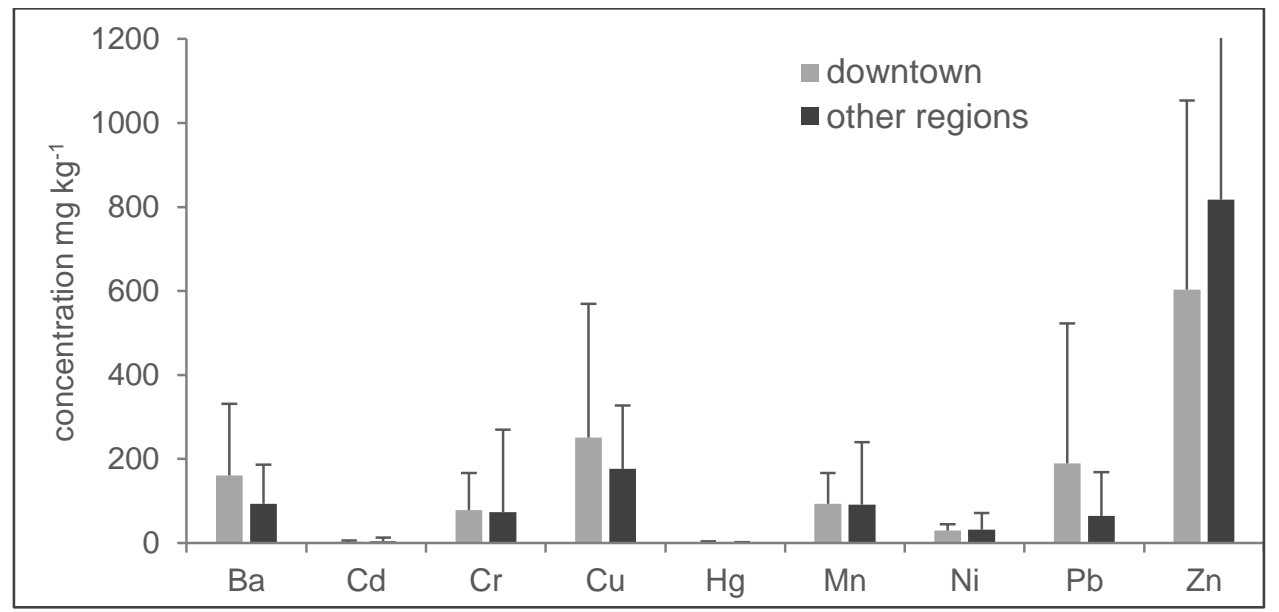

Fig. 17. Comparison of the arithmetic mean concentrations of metals in the household dusts from downtown Toronto and the other regions of GTA, Canada. 


\subsection{Heavy metal concentrations in office, classroom, and laboratory dusts:}

The concentrations of $\mathrm{Ba}, \mathrm{Cd}, \mathrm{Cr}, \mathrm{Cu}, \mathrm{Hg}, \mathrm{Mn}, \mathrm{Ni}, \mathrm{Pb}$, and $\mathrm{Zn}$ in settled dusts collected from offices $(n=11)$, classrooms $(n=11)$, and laboratories $(n=15)$ from the Kerr Hall building at Ryerson University located in the core of downtown Toronto (Fig. 1) are listed in Table 3. The results showed that the metal concentrations in the laboratory dusts were relatively higher than those in the office and classroom dusts. Amongst the heavy metals studied, Zn showed the highest concentrations and $\mathrm{Hg}$ showed the lowest concentrations in all indoor dusts (i.e., the office, classroom, and laboratory dusts). The arithmetic mean concentration of $\mathrm{Zn}$ in laboratory dusts was $3198 \mathrm{mg} \mathrm{kg}^{-1}$, followed by $\mathrm{Cu}\left(631 \mathrm{mg} \mathrm{kg}^{-1}\right), \mathrm{Mn}\left(224 \mathrm{mg} \mathrm{kg}^{-1}\right), \mathrm{Ni}\left(170 \mathrm{mg} \mathrm{kg}^{-1}\right), \mathrm{Ba}$ $\left(154 \mathrm{mg} \mathrm{kg}^{-1}\right), \mathrm{Cr}\left(145 \mathrm{mg} \mathrm{kg}^{-1}\right), \mathrm{Pb}\left(137 \mathrm{mg} \mathrm{kg}^{-1}\right), \mathrm{Cd}\left(25.3 \mathrm{mg} \mathrm{kg}^{-1}\right)$, and $\mathrm{Hg}\left(3.55 \mathrm{mg} \mathrm{kg}^{-1}\right.$; Table 3). In office dusts, the $\mathrm{Zn}$ concentration was $1912 \mathrm{mg} \mathrm{kg}^{-1}$, followed by $\mathrm{Cu}\left(258 \mathrm{mg} \mathrm{kg}^{-}\right.$ $\left.{ }^{1}\right), \mathrm{Ba}\left(99.4 \mathrm{mg} \mathrm{kg}^{-1}\right), \mathrm{Mn}\left(98.9 \mathrm{mg} \mathrm{kg}^{-1}\right), \mathrm{Pb}\left(76.9 \mathrm{mg} \mathrm{kg}^{-1}\right), \mathrm{Cr}\left(63.6 \mathrm{mg} \mathrm{kg}^{-1}\right), \mathrm{Ni}\left(42.3 \mathrm{mg} \mathrm{kg}^{-1}\right)$, $\mathrm{Cd}\left(6.94 \mathrm{mg} \mathrm{kg}^{-1}\right)$, and $\mathrm{Hg}\left(0.94 \mathrm{mg} \mathrm{kg}^{-1}\right.$; Table 3). The concentration of heavy metals in the classroom dusts followed the sequence of $\mathrm{Zn}\left(1353 \mathrm{mg} \mathrm{kg}^{-1}\right), \mathrm{Cu}\left(246 \mathrm{mg} \mathrm{kg}^{-1}\right), \mathrm{Mn}\left(225 \mathrm{mg} \mathrm{kg}^{-}\right.$ $\left.{ }^{1}\right), \mathrm{Ba}\left(121 \mathrm{mg} \mathrm{kg}^{-1}\right), \mathrm{Cr}\left(52.3 \mathrm{mg} \mathrm{kg}^{-1}\right), \mathrm{Pb}\left(49.0 \mathrm{mg} \mathrm{kg}^{-1}\right), \mathrm{Ni}(47.3 \mathrm{mg} \mathrm{kg}-1), \mathrm{Cd}\left(2.47 \mathrm{mg} \mathrm{kg}^{-1}\right)$, and $\mathrm{Hg}\left(0.62 \mathrm{mg} \mathrm{kg}^{-1}\right.$; Table 3). The concentrations of $\mathrm{Cd}, \mathrm{Cr}, \mathrm{Cu}, \mathrm{Ni}$, and $\mathrm{Zn}$ in the laboratory dusts were higher than the $\mathrm{CCME}$ guideline values, whereas $\mathrm{Ba}, \mathrm{Hg}$ and $\mathrm{Pb}$ concentrations were lower than the guideline values specified by CCME (Table 3). The $\mathrm{Cu}$ and $\mathrm{Zn}$ concentrations in the office and classroom dusts were higher than the CCME guideline levels and the rest of the metals (i.e., $\mathrm{Ba}, \mathrm{Cd}, \mathrm{Cr}, \mathrm{Hg}, \mathrm{Ni}$, and $\mathrm{Pb}$ ) were below the $\mathrm{CCME}$ guideline values (Table 3). 
Table 3. Total metal concentrations ( $\mathrm{mg} \mathrm{kg}^{-1}$, dry weight) in the dust samples collected from offices, classrooms, and laboratories in GTA, Canada.

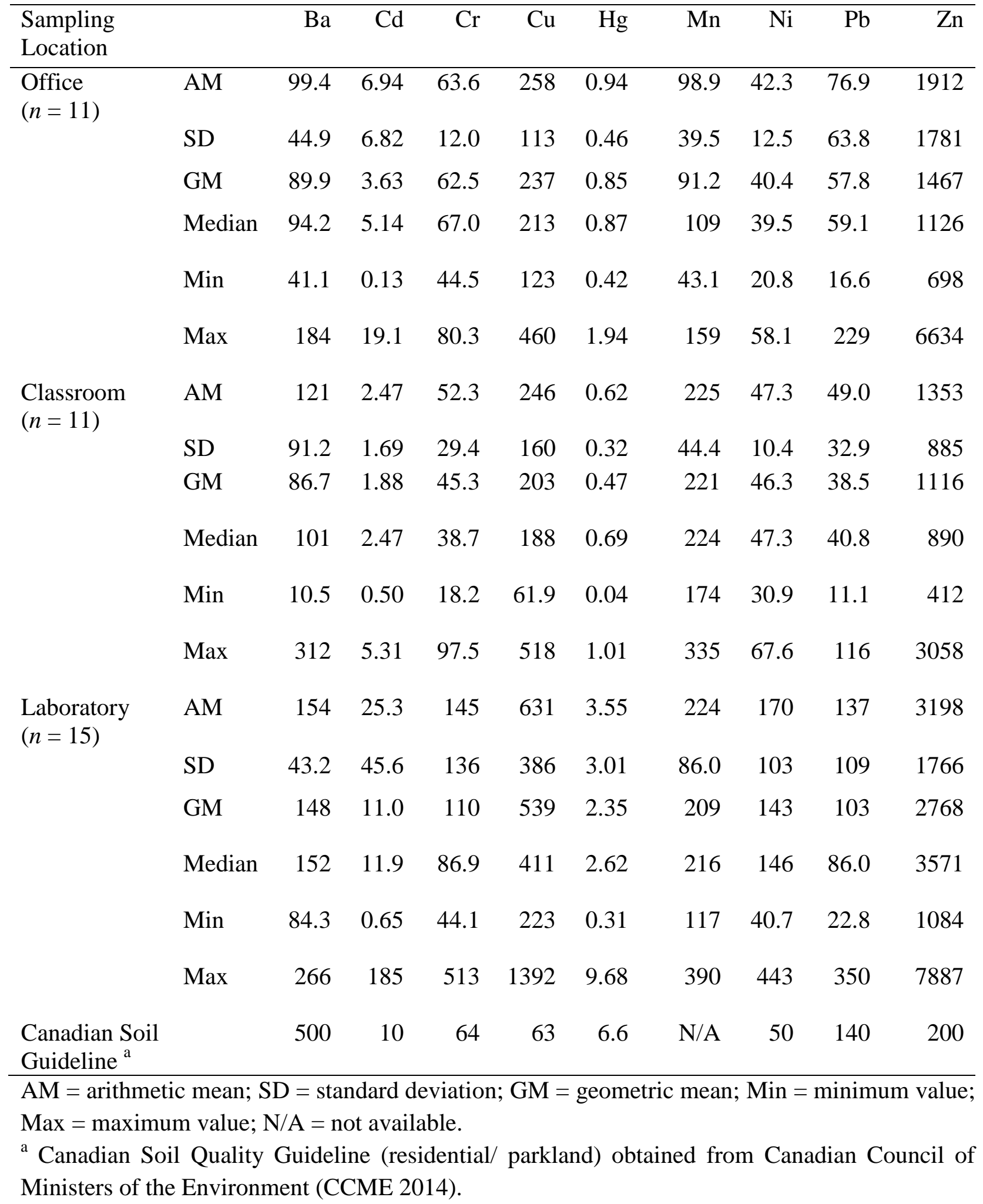




\subsection{Comparison of the results from different indoor environments:}

Figure 18 shows the comparison of metal concentrations in household, office, classroom, and laboratory dusts. In general, the highest levels of metal concentrations were observed in laboratory dusts. This could be attributed to the presence of metallic particles originated from various laboratory equipment and practices, such as chemical reagents, worn metallic constructions, plated, and galvanized surfaces. $\mathrm{Cd}, \mathrm{Cr}, \mathrm{Cu}, \mathrm{Hg}$, and $\mathrm{Ni}$ concentrations in laboratory dusts were significantly higher $(p<0.05)$ than the corresponding concentrations in household, office, and classroom dusts. $\mathrm{Ba}$ and $\mathrm{Pb}$ concentrations in household, office, classroom, and laboratory dusts were statistically comparable. Mn concentrations in laboratory and classroom dusts were comparable and they were significantly higher $(p<0.05)$ than the $\mathrm{Mn}$ concentration in household and office dusts. Zn concentrations in the laboratory, office, and classroom dusts were comparable and they were higher $(p<0.05)$ than the concentrations in household dusts. On the other hand, the Pb level in household dusts collected in downtown Toronto was relatively higher than the $\mathrm{Pb}$ levels in indoor dusts collected from the offices, classrooms, and laboratories (Fig. 18).

In general, metal concentrations in household dusts were lower than those in the laboratory dusts, but they, except $\mathrm{Mn}$ and $\mathrm{Zn}$, were comparable with those in the office and classroom dusts. The Mn concentrations in the classroom dusts were significantly higher $(p<0.05)$ than the concentrations in household dusts, and $\mathrm{Zn}$ concentrations in the office and classroom dusts were higher $(p<0.05)$ than the corresponding values in household dusts (Fig. 18). 

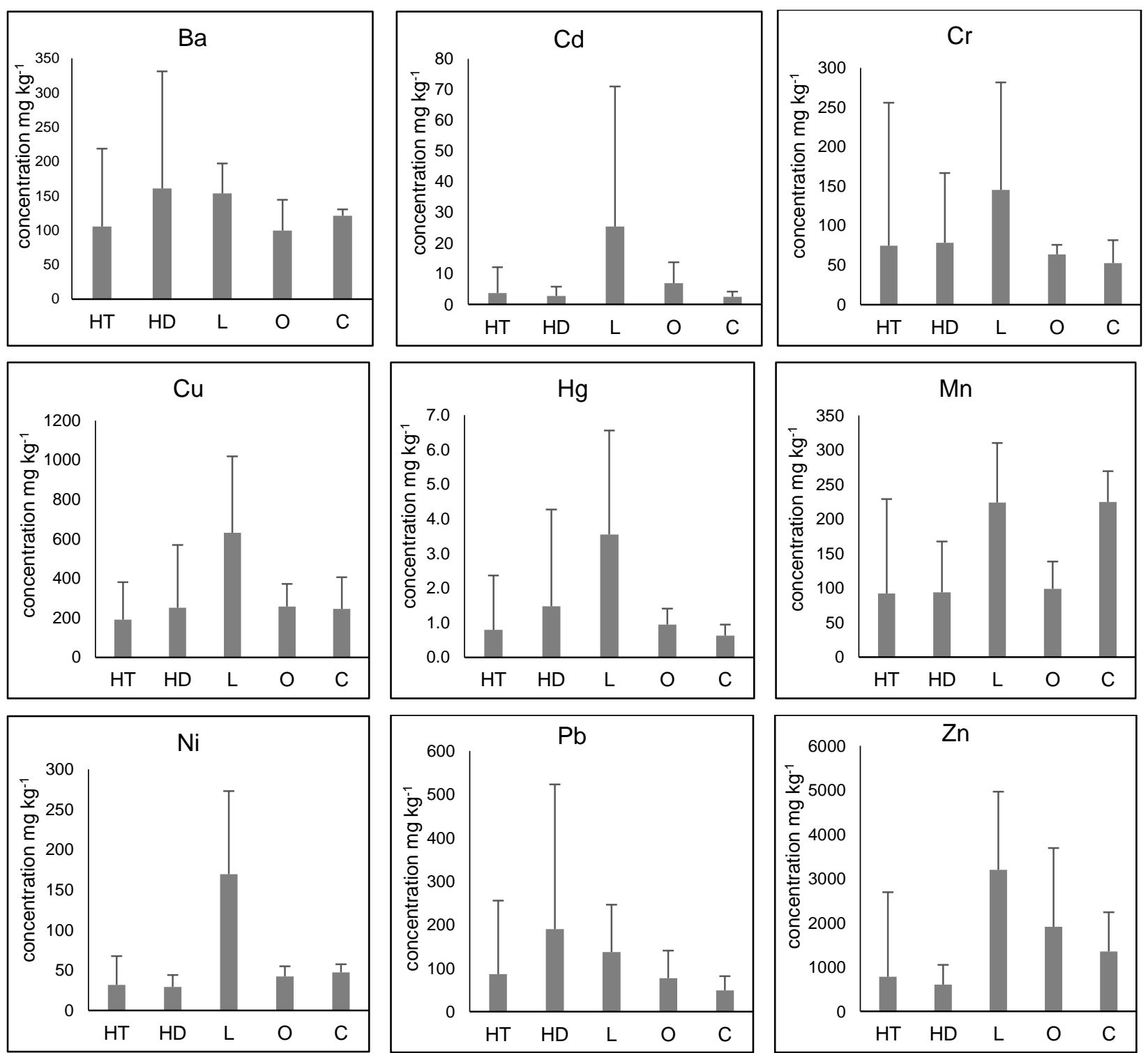

Fig. 18. Comparison of the arithmetic mean concentrations of metals in indoor settled dusts collected from different indoor environments: $\mathrm{HT}=$ House Total; $\mathrm{HD}=$ House Downtown; $\mathrm{L}=$ Laboratory; $\mathrm{O}=$ Office; $\mathrm{C}=$ Classroom. 


\subsection{Comparison of the results observed in this study with literature values:}

The concentrations of heavy metals found in the present study with those reported in different cities around the world are compared in Table 4. The Ba concentrations in household dusts in Toronto were lower than the values reported for Ottawa, Canada (Rasmussen et al. 2001) and Dharan, S. Arabia (Turner and Hefzi 2010), but they were higher than those in Amman, Jordan (Al-Momani 2007). The $\mathrm{Cr}$ and $\mathrm{Pb}$ levels in household dusts in Toronto were lower compared with the levels reported for Sydney, Australia (Chattopadyay et al. 2003), Pretoria, South Africa (Kefeni and Okonkwo 2013), Amman, and Ottawa. Whereas, the Cr and $\mathrm{Pb}$ levels in Toronto were higher than those for Istanbul, Turkey (Kurt-Karakus 2012) and Dharan. Lower Cd concentrations were observed in household dusts in Toronto compared with those found in Amman, Sydney, and Ottawa whereas the Cd level in Toronto was higher than Istanbul, Pretoria, and Dharan. Elevation of $\mathrm{Cu}$ in household dusts was found in the present study when compared with Amman, Sydney, Istanbul, Pretoria, and Dharan and lower when compared to Ottawa.

Limited data were available in literature about $\mathrm{Hg}$ concentrations in household dusts. However, the concentrations found in Toronto were lower than those in Ottawa and higher than Dharan (Table 4). Mn levels in Toronto were lower than the levels reported for Amman, Ottawa, Istanbul, Pretoria, and Dharan, but higher than those found for Sydney. Ni concentrations were lower compared with the concentrations reported for Amman, Ottawa, Istanbul, and Pretoria and higher compared with Sydney and Dharan. The Zn concentrations found from this study were lower than Amman and Istanbul, but higher than Ottawa, Sydney, Pretoria, and Dharan. On the other hand, the concentrations of heavy metals in office dusts in Toronto were lower than those reported for Istanbul and Pretoria except $\mathrm{Cd}$ and $\mathrm{Zn}$. Cd concentrations were higher than Istanbul 
and Pretoria while $\mathrm{Zn}$ concentrations were higher than those found for Pretoria (Table 4). In general, the concentrations of heavy metals in indoor dusts in Toronto were in the range of the values reported in literature for a number of locations worldwide.

Table 4. Comparison of the arithmetic mean concentrations $\left(\mathrm{mg} \mathrm{kg}^{-1}\right)$ of heavy metals in indoor dusts presented in this study with those reported in literature.

\begin{tabular}{|c|c|c|c|c|c|c|c|c|c|c|c|c|c|}
\hline Location & $n$ & $\begin{array}{l}\text { Sampling } \\
\text { method }\end{array}$ & Source & $\mathrm{Ba}$ & $\mathrm{Cd}$ & $\mathrm{Cr}$ & $\mathrm{Cu}$ & $\mathrm{Hg}$ & $\mathrm{Mn}$ & $\mathrm{Ni}$ & $\mathrm{Pb}$ & $\mathrm{Zn}$ & Reference \\
\hline $\begin{array}{l}\text { Toronto, } \\
\text { Canada }\end{array}$ & 67 & $\begin{array}{l}\text { Gentle } \\
\text { sweeping }\end{array}$ & House & 106 & 3.73 & 74.7 & 191 & 0.80 & 92.1 & 31.8 & 86.3 & 778 & This study \\
\hline $\begin{array}{l}\text { Toronto, } \\
\text { Canada }\end{array}$ & 11 & $\begin{array}{l}\text { Gentle } \\
\text { sweeping }\end{array}$ & Office & 99.4 & 6.94 & 63.6 & 258 & 0.94 & 98.9 & 42.3 & 76.9 & 1912 & This study \\
\hline $\begin{array}{l}\text { Toronto, } \\
\text { Canada }\end{array}$ & 11 & $\begin{array}{l}\text { Gentle } \\
\text { sweeping }\end{array}$ & Class & 121 & 2.47 & 52.3 & 246 & 0.62 & 225 & 47.3 & 49.0 & 1353 & This study \\
\hline $\begin{array}{l}\text { Toronto, } \\
\text { Canada }\end{array}$ & 15 & $\begin{array}{l}\text { Gentle } \\
\text { sweeping }\end{array}$ & Lab & 154 & 25.3 & 145 & 631 & 3.55 & 224 & 170 & 137 & 3198 & This study \\
\hline $\begin{array}{l}\text { Amman, } \\
\text { Jordan }\end{array}$ & 20 & $\begin{array}{l}\text { Vacuum } \\
\text { cleaner }\end{array}$ & House & 85 & 4.46 & 77 & 160 & $\ldots$ & 284 & 47 & 206 & 3104 & $\begin{array}{l}\text { Al-Momani } \\
2007\end{array}$ \\
\hline $\begin{array}{l}\text { Sydney, } \\
\text { Australia }\end{array}$ & 82 & $\begin{array}{l}\text { Vacuum } \\
\text { cleaner }\end{array}$ & House & $\ldots$ & 4.4 & 83.6 & 147 & $\ldots$ & 76.1 & 27.2 & 389 & 657 & $\begin{array}{l}\text { Chattopad- } \\
\text { hay } 2003\end{array}$ \\
\hline $\begin{array}{l}\text { Ottawa, } \\
\text { Canada }\end{array}$ & 50 & $\begin{array}{l}\text { Vacuum } \\
\text { cleaner }\end{array}$ & House & 492 & 6.46 & 86.7 & 206 & 3.63 & 269 & 62.9 & 406 & 716 & $\begin{array}{l}\text { Rasmussen } \\
\text { et al. } 2001\end{array}$ \\
\hline $\begin{array}{l}\text { Istanbul, } \\
\text { Turkey }^{\mathrm{a}}\end{array}$ & 8 & $\begin{array}{l}\text { Vacuum } \\
\text { cleaner }\end{array}$ & Office & $\ldots$ & 1.8 & 254 & 513 & $\ldots$ & 655 & 471 & 192 & 1970 & $\begin{array}{l}\text { Kurt-Kara- } \\
\text { kus } 2012\end{array}$ \\
\hline $\begin{array}{l}\text { Istanbul, } \\
\text { Turkey }^{\mathrm{a}}\end{array}$ & 31 & $\begin{array}{l}\text { Vacuum } \\
\text { cleaner }\end{array}$ & House & $\ldots$ & 0.80 & 55 & 156 & $\ldots$ & 136 & 263 & 28 & 832 & $\begin{array}{l}\text { Kurt-Kara- } \\
\text { kus } 2012\end{array}$ \\
\hline $\begin{array}{l}\text { Pretoria, } \\
\text { South } \\
\text { Africa }\end{array}$ & 6 & $\begin{array}{l}\text { Vacuum } \\
\text { cleaner }\end{array}$ & Office & $\ldots$ & 2.53 & 160 & 2740 & $\ldots$ & 772 & 69.8 & 126 & 1300 & $\begin{array}{l}\text { Kefeni and } \\
\text { Okonkwo } \\
2013\end{array}$ \\
\hline $\begin{array}{l}\text { Pretoria, } \\
\text { South } \\
\text { Africa }\end{array}$ & 8 & $\begin{array}{l}\text { Vacuum } \\
\text { cleaner }\end{array}$ & House & $\ldots$ & 1.47 & 109 & 186 & $\ldots$ & 457 & 59.5 & 110 & 669 & $\begin{array}{l}\text { Kefeni and } \\
\text { Okonkwo } \\
2013\end{array}$ \\
\hline $\begin{array}{l}\text { Dharan, } \\
\text { S. Arabia }\end{array}$ & 9 & $\begin{array}{l}\text { Vacuum } \\
\text { cleaner }\end{array}$ & House & 426 & 1.51 & 37 & 91.1 & 0.20 & 121 & 26.1 & 35.5 & 396 & $\begin{array}{l}\text { Turner and } \\
\text { Hefzi } 2010\end{array}$ \\
\hline
\end{tabular}

${ }^{\mathrm{a}}$ Median values are reported. 


\subsection{Heavy metal correlations:}

Correlations between heavy metals could be a useful tool to get some information on the sources of metals in indoor environments (Manta et al. 2002; Hassan 2012). The Pearson's correlation coefficients (r) between heavy metals in household dusts are given in Table 5. No significant correlations were observed between $\mathrm{Hg}$ and other metals, which may indicate different sources of $\mathrm{Hg}$ from other metals. Strong correlations were found between $\mathrm{Ba}$ and $\mathrm{Mn}(\mathrm{r}$ $=0.79, p<0.01)$, Mn and $\mathrm{Ni}(\mathrm{r}=0.71, p<0.01)$, and $\mathrm{Mn}$ and $\mathrm{Zn}(\mathrm{r}=0.72, p<0.01)$. The strong correlations may imply common sources of these metals. Moderate correlations $(r=0.5-0.6)$ were found between the following pairs of metals: $\mathrm{Ba}-\mathrm{Ni}, \mathrm{Ba}-\mathrm{Pb}, \mathrm{Ba}-\mathrm{Zn}, \mathrm{Cd}-\mathrm{Pb}, \mathrm{Cr}-\mathrm{Mn}$, $\mathrm{Cr}-\mathrm{Pb}, \mathrm{Cu}-\mathrm{Mn}, \mathrm{Cu}-\mathrm{Zn}, \mathrm{Mn}-\mathrm{Pb}, \mathrm{Ni}-\mathrm{Pb}$, and $\mathrm{Pb}-\mathrm{Zn}$ (Table 5). These pairs of metals may partially share similar sources. Weak correlations $(\mathrm{r}<0.5)$ between $\mathrm{Ba}$ and $\mathrm{Cd}, \mathrm{Ba}$ and $\mathrm{Cr}, \mathrm{Ba}$ and $\mathrm{Cu}, \mathrm{Cd}$ and $\mathrm{Cr}, \mathrm{Cd}$ and $\mathrm{Cu}, \mathrm{Cd}$ and $\mathrm{Mn}, \mathrm{Cd}$ and $\mathrm{Ni}, \mathrm{Cr}$ and $\mathrm{Cu}, \mathrm{Cr}$ and $\mathrm{Zn}, \mathrm{Cu}$ and $\mathrm{Ni}, \mathrm{Cu}$ and $\mathrm{Pb}$, and $\mathrm{Ni}$ and $\mathrm{Zn}$ (Table 5) may suggest different sources of these metals (Yaghi and AbduWahab 2004, Al-Momani 2007).

Correlations between metals for office dusts are shown in Table 6. Strong correlations were found between $\mathrm{Mn}$ and the following metals: $\mathrm{Ba}(\mathrm{r}=0.84, p<0.01), \mathrm{Cd}(\mathrm{r}=0.72, p<$ $0.05)$, and $\mathrm{Cu}(\mathrm{r}=0.82, p<0.01)$. Also, a strong correlation was observed between $\mathrm{Pb}$ and $\mathrm{Cd}(\mathrm{r}$ $=0.79, p<0.01)$. Moderate correlations $(\mathrm{r} \sim 0.6, p<0.05)$ were found among $\mathrm{Ba}, \mathrm{Cu}$, and $\mathrm{Ni}$ (Table 6). 
Table 5. Inter-metal correlations for the household dusts.

\begin{tabular}{lrrrrrrrrr}
\hline & $\mathrm{Ba}$ & $\mathrm{Cd}$ & $\mathrm{Cr}$ & $\mathrm{Cu}$ & $\mathrm{Hg}$ & $\mathrm{Mn}$ & $\mathrm{Ni}$ & $\mathrm{Pb}$ & $\mathrm{Zn}$ \\
\hline $\mathrm{Ba}$ & 1 & & & & & & & & \\
$\mathrm{Cd}$ & $0.38^{* *}$ & 1 & & & & & & & \\
$\mathrm{Cr}$ & $0.47^{* *}$ & $0.30^{*}$ & 1 & & & & & & \\
$\mathrm{Cu}$ & $0.45^{* *}$ & 0.13 & $0.28^{*}$ & 1 & & & & & \\
$\mathrm{Hg}$ & 0.15 & 0.08 & 0.12 & $0.29^{*}$ & 1 & & & & \\
$\mathrm{Mn}$ & $0.79^{* *}$ & $0.27^{*}$ & $0.58^{*}$ & $0.56^{* *}$ & 0.17 & 1 & & & \\
$\mathrm{Ni}$ & $0.63^{* *}$ & $0.38^{* *}$ & $0.67^{* *}$ & $0.35^{* *}$ & 0.05 & $0.71^{* *}$ & 1 & & \\
$\mathrm{~Pb}$ & $0.58^{* *}$ & $0.59^{* *}$ & $0.57^{* *}$ & $0.37^{* *}$ & 0.06 & $0.61^{* *}$ & $0.66^{* *}$ & 1 & \\
$\mathrm{Zn}$ & $0.56^{* *}$ & $0.29^{*}$ & $0.44^{* *}$ & $0.58^{* *}$ & 0.18 & $0.72^{* *}$ & $0.47^{* *}$ & $0.57^{* *}$ & 1 \\
\hline
\end{tabular}

* Correlation is significant at $p<0.05$

** Correlation is significant at $p<0.01$

Table 6. Inter-metal correlations for the office dusts.

\begin{tabular}{lrrrrrrrrr}
\hline & $\mathrm{Ba}$ & $\mathrm{Cd}$ & $\mathrm{Cr}$ & $\mathrm{Cu}$ & $\mathrm{Hg}$ & $\mathrm{Mn}$ & $\mathrm{Ni}$ & $\mathrm{Pb}$ & $\mathrm{Zn}$ \\
\hline $\mathrm{Ba}$ & 1 & & & & & & & & \\
$\mathrm{Cd}$ & 0.53 & 1 & & & & & & & \\
$\mathrm{Cr}$ & -0.20 & -0.26 & 1 & & & & & & \\
$\mathrm{Cu}$ & $0.64^{*}$ & 0.57 & -0.11 & 1 & & & & & \\
$\mathrm{Hg}$ & 0.06 & 0.43 & -0.35 & -0.27 & 1 & & & & \\
$\mathrm{Mn}$ & $0.84^{* *}$ & $0.72^{*}$ & -0.14 & $0.82^{* *}$ & -0.08 & 1 & & & \\
$\mathrm{Ni}$ & $0.61^{*}$ & 0.33 & -0.55 & $0.60^{*}$ & 0.09 & 0.52 & 1 & & \\
$\mathrm{~Pb}$ & 0.32 & $0.79^{* *}$ & -0.06 & 0.12 & 0.55 & 0.43 & 0.10 & 1 & \\
$\mathrm{Zn}$ & 0.15 & $0.62^{*}$ & 0.00 & 0.28 & 0.46 & 0.42 & -0.12 & 0.40 & 1 \\
\hline
\end{tabular}

* Correlation is significant at $p<0.05$

** Correlation is significant at $p<0.01$ 
Table 7 shows the correlations between heavy metals for the laboratory dusts. Strong correlation was found between $\mathrm{Cd}$ and $\mathrm{Pb}(\mathrm{r}=0.88, p<0.01)$, which was approximately the same correlation observed for the office dusts. Moderate correlations were found between $\mathrm{Ba}$ and Mn $(\mathrm{r}=0.55, p<0.05), \mathrm{Cd}$ and $\mathrm{Hg}(\mathrm{r}=0.58, p<0.05), \mathrm{Cr}$ and $\mathrm{Ni}(\mathrm{r}=0.68, p<0.01), \mathrm{Hg}$ and $\mathrm{Pb}$ $(\mathrm{r}=0.69, p<0.01)$, and $\mathrm{Pb}$ and $\mathrm{Zn}(\mathrm{r}=0.55, p<0.05)$.

Table 7. Inter-metal correlations for the laboratory dusts.

\begin{tabular}{lrrrrrrrrr}
\hline & $\mathrm{Ba}$ & $\mathrm{Cd}$ & $\mathrm{Cr}$ & $\mathrm{Cu}$ & $\mathrm{Hg}$ & $\mathrm{Mn}$ & $\mathrm{Ni}$ & $\mathrm{Pb}$ & $\mathrm{Zn}$ \\
\hline $\mathrm{Ba}$ & 1 & & & & & & & & \\
$\mathrm{Cd}$ & 0.39 & 1 & & & & & & & \\
$\mathrm{Cr}$ & 0.03 & 0.03 & 1 & & & & & & \\
$\mathrm{Cu}$ & 0.24 & -0.09 & -0.15 & 1 & & & & & \\
$\mathrm{Hg}$ & 0.12 & $0.58^{*}$ & -0.20 & 0.36 & 1 & & & & \\
$\mathrm{Mn}$ & $0.55^{*}$ & 0.40 & 0.32 & -0.27 & -0.23 & 1 & & & \\
$\mathrm{Ni}$ & -0.14 & 0.37 & $0.68^{* *}$ & -0.13 & 0.30 & 0.13 & 1 & & \\
$\mathrm{~Pb}$ & 0.41 & $0.88^{* *}$ & -0.12 & 0.10 & $0.69^{* *}$ & 0.25 & 0.28 & 1 & \\
$\mathrm{Zn}$ & 0.03 & 0.23 & -0.01 & 0.14 & 0.30 & -0.06 & 0.20 & $0.55^{*}$ & 1 \\
\hline
\end{tabular}

${ }^{*}$ Correlation is significant at $p<0.05$

${ }^{*}$ Correlation is significant at $p<0.01$

The correlations between metals for classroom dusts are given in Table 8. Most of the metals were strongly or moderately correlated with each other. In general, the pattern of the correlations between the metals for various indoor dusts (i.e., household, office, classroom, and laboratory dusts) seems to be different from one indoor environment to another. This might be attributed to a huge number and variety of sources of heavy metals available in indoor dusts. 
Table 8. Inter-metal correlations for the classroom dusts.

\begin{tabular}{lrrrrrrrrr}
\hline & $\mathrm{Ba}$ & $\mathrm{Cd}$ & $\mathrm{Cr}$ & $\mathrm{Cu}$ & $\mathrm{Hg}$ & $\mathrm{Mn}$ & $\mathrm{Ni}$ & $\mathrm{Pb}$ & $\mathrm{Zn}$ \\
\hline $\mathrm{Ba}$ & 1 & & & & & & & & \\
$\mathrm{Cd}$ & $0.75^{* *}$ & 1 & & & & & & & \\
$\mathrm{Cr}$ & $0.76^{* *}$ & $0.64^{*}$ & 1 & & & & & & \\
$\mathrm{Cu}$ & $0.84^{* *}$ & $0.76^{* *}$ & $0.82^{* *}$ & 1 & & & & & \\
$\mathrm{Hg}$ & $0.77^{* *}$ & 0.60 & $0.63^{*}$ & $0.90^{* *}$ & 1 & & & & \\
$\mathrm{Mn}$ & $0.72^{*}$ & $0.69^{*}$ & 0.59 & 0.56 & 0.37 & 1 & & & \\
$\mathrm{Ni}$ & 0.48 & $0.61^{*}$ & $0.71^{*}$ & 0.56 & 0.27 & $0.71^{*}$ & 1 & & \\
$\mathrm{~Pb}$ & $0.84^{* *}$ & $0.87^{* *}$ & $0.64^{*}$ & $0.80^{* *}$ & $0.69^{*}$ & $0.78^{* *}$ & 0.52 & 1 & \\
$\mathrm{Zn}$ & $0.85^{* *}$ & $0.77^{* *}$ & $0.74^{* *}$ & $0.91^{* *}$ & $0.75^{* *}$ & 0.59 & 0.55 & $0.78^{* *}$ & 1 \\
\hline
\end{tabular}

* Correlation is significant at $p<0.05$

** Correlation is significant at $p<0.01$

\subsection{Enrichment of measured metals:}

Enrichment factors (EF) of heavy metals can provide useful information about the degree of enrichment of the metals in dust samples compared to their abundance in earth's crust (AlMomani 2007). Moreover, the EF can be used to distinguish between the metals originating from human activities (anthropogenic sources) and those from natural origin (Meza-Figueroa et al. 2007). The EF can be calculated from the following equation (Al-Momani 2007, Lu et al. 2014):

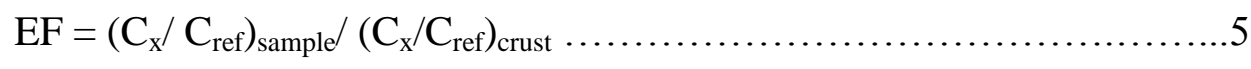

where $C_{x}$ is the concentration of the metal of interest and $C_{\text {ref }}$ is the concentration of the reference metal for normalization. The data on the average abundances of the metals in the earth's crust reported by Mason and Moore (1982) were used in the present study for the metal concentrations in the crust. Mn was used as a reference metal (Loska et al. 1997; Uduma and 
Awagu 2013) assuming that its anthropogenic sources are insignificant. The enrichment factor value close to one indicates natural origin (natural level). Whereas, the EF value greater than 10 is used as an indicator of contamination from anthropogenic sources (Al-Momani 2007; MezaFigueroa et al. 2007; Lu et al. 2014). The calculated enrichment factors for the metals in household, office, classroom, and laboratory dusts are shown in Table 9. $\mathrm{Cd}, \mathrm{Cu}, \mathrm{Hg}, \mathrm{Pb}$, and $\mathrm{Zn}$ in all indoor dusts studied had enrichment factors greater than 10 (Table 9), which indicated that anthropogenic sources were the predominant sources of these metals. Also, the higher EF values may refer to the significant internal sources of these metals (Turner and Simmonds 2006). On the other hand, the $\mathrm{EF}$ values of $\mathrm{Cr}$ and $\mathrm{Ni}$ were, in general, lower than 10, which suggested that these metals partially originated from anthropogenic sources and moderately contaminated by these metals. The natural origin was the main source of $\mathrm{Ba}$ in all indoor dusts as its EF value was close to one (Table 9).

Table 9. Enrichment factors for heavy metals in the indoor dust samples.

\begin{tabular}{lrrrrrrrrr}
\hline Location & $\mathrm{Ba}$ & $\mathrm{Cd}$ & $\mathrm{Cr}$ & $\mathrm{Cu}$ & $\mathrm{Hg}$ & $\mathrm{Mn}$ & $\mathrm{Ni}$ & $\mathrm{Pb}$ & $\mathrm{Zn}$ \\
\hline House & 3.1 & 345 & 10.2 & 52.8 & 170 & 1 & 6.1 & 82.9 & 128 \\
Office & 2.3 & 268 & 7.4 & 46.2 & 132 & 1 & 6.0 & 52.5 & 268 \\
Classroom & 1.1 & 36 & 2.2 & 16.5 & 33.1 & 1 & 2.7 & 15.0 & 79 \\
Laboratory & 1.7 & 554 & 6.4 & 59.7 & 248 & 1 & 10.7 & 49.6 & 224 \\
\hline
\end{tabular}

Looking at Table 9, it can be seen that the EF values of $\mathrm{Cd}, \mathrm{Hg}$, and $\mathrm{Zn}$ in household, office, and laboratory dusts were higher than 100, which could be indicative of gross contamination. The EF values of the heavy metals studied in the classroom dusts were less than 
the corresponding values in household, office, and laboratory dusts (Table 9). Therefore, the least contamination levels of the heavy metals were in the classroom dusts.

\section{CONCLUSIONS:}

The present study is the first of its kind in Toronto. It has provided baseline data for metal concentrations in the Toronto household dusts and office, classroom, and laboratory dusts as well. The results showed that no significant differences were observed in the concentrations of metals (except Mn and Zn) in household, office, and classroom dusts. Among the studied indoor dusts, the laboratory dusts exhibited the highest concentrations of the metals under investigation. However, elevated levels of $\mathrm{Pb}$ were found in downtown Toronto household dusts compared with the other regions of the GTA household dusts as well as office, classroom, and laboratory dusts. According to the $\mathrm{CCME}$ guideline, $\mathrm{Cr}, \mathrm{Cu}$ and $\mathrm{Zn}$ concentrations in household dusts, $\mathrm{Cu}$ and $\mathrm{Zn}$ in office, classroom dusts and $\mathrm{Cd}, \mathrm{Cr}, \mathrm{Cu}, \mathrm{Ni}$, and $\mathrm{Zn}$ in laboratory dusts exceeded the acceptable limits. On the other hand, metal concentrations in indoor dusts were, in general, in the range of the corresponding values reported in literature for a variety of locations worldwide. Different correlation patterns were observed between metal concentrations. This might be attributed to the large number of different anthropogenic sources of the metals in the indoor environments. Based on crustal backgrounds, $\mathrm{Cd}, \mathrm{Cu}, \mathrm{Hg}, \mathrm{Pb}$, and $\mathrm{Zn}$ in the indoor dusts were highly enriched (with EF values exceeded 100 for $\mathrm{Cd}, \mathrm{Hg}$, and $\mathrm{Zn}$ ) indicating anthropogenic sources for these metals in the indoor environments. Further detailed investigations are needed to identify the potential sources that contribute to the enrichment of these metals. This study suggest that indoor settled dusts can be used as an indicator for heavy metal pollution in indoor environments. 


\section{FUTURE WORK:}

Besides heavy metals in indoor dusts, metals in exterior dusts and soils should be analyzed and correlated to figure out the impact of external sources of the metals on the indoor dusts. The speciation of metals and their health risks need to be studied. The bioaccessibilities of metals in indoor dusts also should be conducted to obtain default values for risk assessments. Finally, organic pollutants, such as polycyclic aromatic hydrocarbons, which cause cancer, should be included for the future monitoring studies besides the heavy metals. 


\section{APPENDIX:}

Table A-1. Operation conditions for the ICP-AES analysis of heavy metals in dust samples.

\begin{tabular}{ll}
\hline Parameter & Value \\
\hline RF power & $1200 \mathrm{~W}$ \\
Auxiliary gas flow rate & $20 \mathrm{~mL} \mathrm{~min}^{-1}$ \\
Coolant gas flow rate & $40 \mathrm{~mL} \mathrm{~min}^{-1}$ \\
Nebulizer gas flow rate & $30 \mathrm{~mL} \mathrm{~min}^{-1}$ \\
Integration time & $10 \mathrm{~s}^{-}$ \\
Analyte lines & $\mathrm{Ba} 455.403 \mathrm{~nm}, \mathrm{Cd} 226.502 \mathrm{~nm}, \mathrm{Cr} 267.716 \mathrm{~nm}, \mathrm{Cu} 654.792$ \\
& $\mathrm{~nm}, \mathrm{Mn} 257.610 \mathrm{~nm}, \mathrm{Ni} 231.604 \mathrm{~nm}, \mathrm{~Pb} 168.215 \mathrm{~nm}, \mathrm{Zn}$ \\
& $213.856 \mathrm{~nm}$ \\
\hline
\end{tabular}


Table A-2. Calibration of CVAFS for the determination of total mercury (the average of bubbler blanks $=30602$ ).

\begin{tabular}{|c|c|c|c|c|c|c|}
\hline & $\begin{array}{l}\text { Concentration } \\
\left(\mathrm{ng} \mathrm{L}^{-1}\right)\end{array}$ & Peak Area & $\begin{array}{l}\text { Net Peak } \\
\text { Area }\end{array}$ & $\begin{array}{l}\text { Calibration } \\
\text { Factor }\left(\mathrm{CF}_{\mathrm{x}}\right)\end{array}$ & $\begin{array}{l}\text { Measured } \\
\text { Concentration }^{\mathrm{a}}\end{array}$ & $\begin{array}{l}\% \\
\text { Recovery }\end{array}$ \\
\hline \multirow[t]{5}{*}{ First Trial } & 0.5 & 47056 & 16454 & 32908 & 0.39 & 78 \\
\hline & 5.0 & 242324 & 211722 & 42344 & 5.0 & 100 \\
\hline & 25.0 & 1144836 & 1114234 & 44569 & 26.4 & 105 \\
\hline & 50.0 & 2287323 & 2256721 & 45134 & 53.4 & 107 \\
\hline & 100.0 & 4531930 & 4501328 & 45013 & 106.5 & 106 \\
\hline \multirow[t]{5}{*}{ Second Trial } & 0.50 & 47558 & 16956 & 33912 & 0.40 & 80 \\
\hline & 5.0 & 242018 & 211416 & 42283 & 5.0 & 100 \\
\hline & 25.0 & 1145276 & 1114674 & 44587 & 26.4 & 105 \\
\hline & 50.0 & 2303936 & 2273334 & 45467 & 53.8 & 108 \\
\hline & 100.0 & 4499615 & 4469013 & 44690 & 105.7 & 106 \\
\hline \multirow[t]{5}{*}{ Third Trial } & 0.50 & 46156 & 15554 & 31108 & 0.37 & 74 \\
\hline & 5.0 & 245085 & 214483 & 42897 & 5.1 & 101 \\
\hline & 25.0 & 1173213 & 1142611 & 45704 & 27.0 & 108 \\
\hline & 50.0 & 2436701 & 2406099 & 48122 & 56.9 & 114 \\
\hline & 100.0 & 4568982 & 4538380 & 45384 & 107.3 & 107 \\
\hline Mean $\left(\mathrm{CF}_{\mathrm{m}}\right)$ & & & & 42275 & & \\
\hline $\mathrm{SD}$ & & & & 5215 & & \\
\hline$\%$ RSD & & & & 12 & & \\
\hline
\end{tabular}

${ }^{\mathrm{a}}$ Measured concentration $\left(\mathrm{ng} \mathrm{\textrm {L } ^ { - 1 }}\right)=$ Net peak area/ $\mathrm{CF}_{\mathrm{m}}$. 
Table A-3. Method detection limit (MDL) for the CVAFS analysis of THg using seven replicates of $2.5 \mathrm{ng} \mathrm{L}^{-1}$ based on EPA Method 40 CFR 136, Appendix. $\left(\mathrm{CF}_{\mathrm{m}}=42275\right)$.

\begin{tabular}{lrrr}
\hline $\begin{array}{l}\text { Replicate }\left(2.5 \mathrm{ng} \mathrm{L}^{-1}\right) \\
\text { Number }\end{array}$ & Net Peak Area & $\begin{array}{l}\text { Measured Concentration } \\
\left(\mathrm{ng} \mathrm{L}^{-1}\right)\end{array}$ & $\begin{array}{l}\text { Measured Concentration } \\
\left(\mathrm{ng} \mathrm{g}^{-1}\right)^{\mathrm{a}}\end{array}$ \\
\hline 1 & 127191 & 3.00 & 1.00 \\
2 & 128615 & 3.04 & 0.80 \\
3 & 101765 & 2.41 & 0.79 \\
4 & 99580 & 2.36 & 0.90 \\
5 & 114275 & 2.70 & 0.89 \\
6 & 113293 & 2.68 & 1.24 \\
7 & 156803 & 3.71 & 0.95 \\
Mean & & & 0.16 \\
SD & & & 0.49 \\
MDL & & &
\end{tabular}

\footnotetext{
${ }^{\mathrm{a}}$ Measured concentration $\left(\mathrm{ng} \mathrm{g}^{-1}\right)=$ Measured concentration $\left(\mathrm{ng} \mathrm{L}^{-1}\right)$ x volume (L)/ weight $(\mathrm{g})$, where the volume of digestate is $50 \mathrm{~mL}(0.05 \mathrm{~L})$ and the weight is taken as $0.15 \mathrm{~g}$.
} 
Table A-4. Initial precision and recovery (IPR) for the CVAFS analysis of THg using four replicate of $5 \mathrm{ng} \mathrm{L}^{-1}$ according to the EPA Method 1631B and Appendix to Method 1631. $\left(\mathrm{CF}_{\mathrm{m}}=\right.$ 42275).

\begin{tabular}{lrrr}
\hline $\begin{array}{l}\text { Replicate }\left(5 \mathrm{ng} \mathrm{L}^{-1}\right) \\
\text { Number }\end{array}$ & Net Peak Area & $\begin{array}{l}\text { Measured Concentration } \\
\left(\mathrm{ng} \mathrm{L}^{-1}\right)\end{array}$ & \% Recovery \\
\hline 1 & 209560 & 4.96 & 99 \\
2 & 219101 & 5.18 & 104 \\
3 & 222279 & 5.26 & 105 \\
4 & 232568 & 5.50 & 110 \\
Mean & & & 104 \\
SD & & & 4 \\
$\%$ RSD & & 4 \\
\hline
\end{tabular}



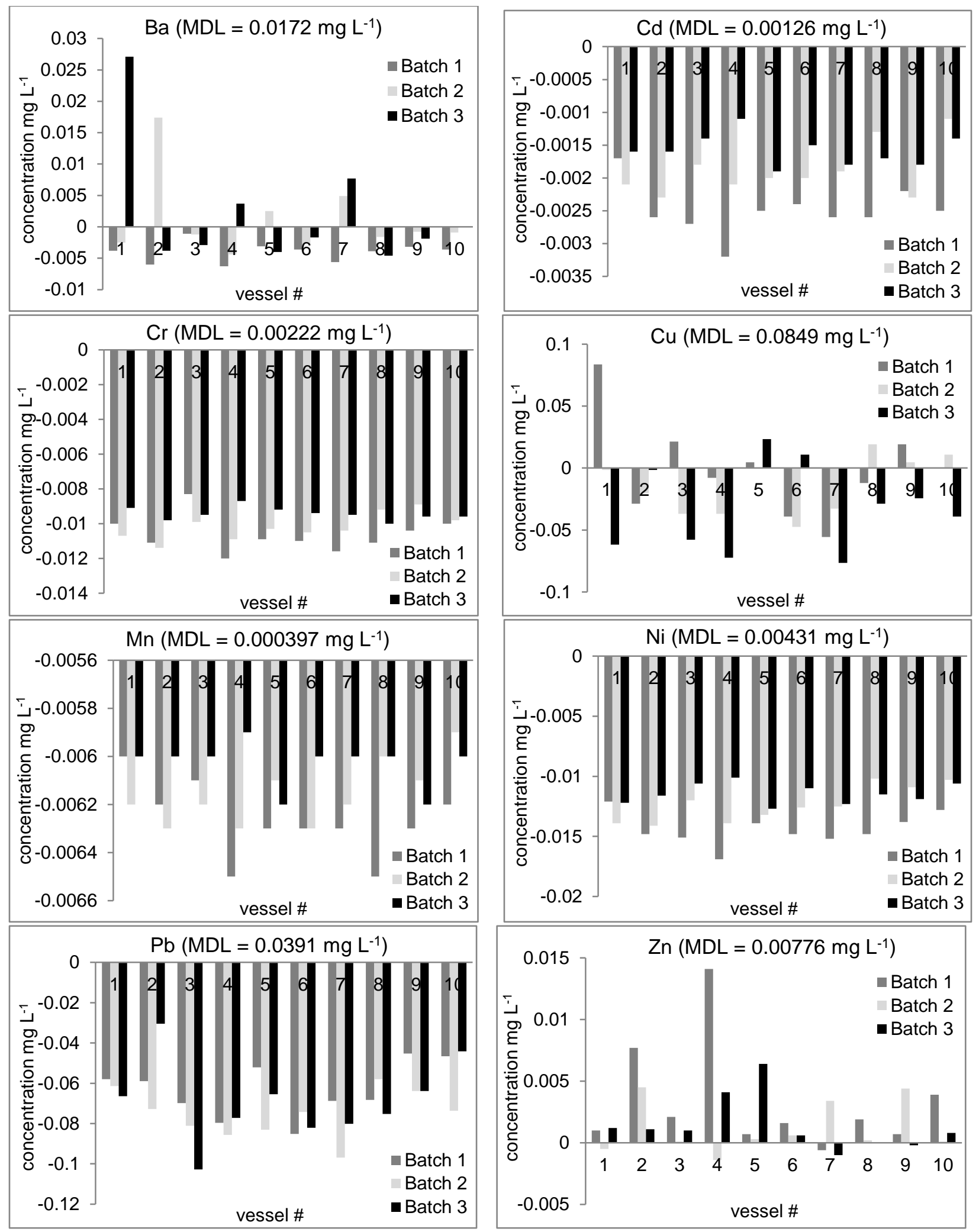

Fig. A-1. Results of the ICP-AES analysis for three batches of blanks (10 blanks for each batch). 

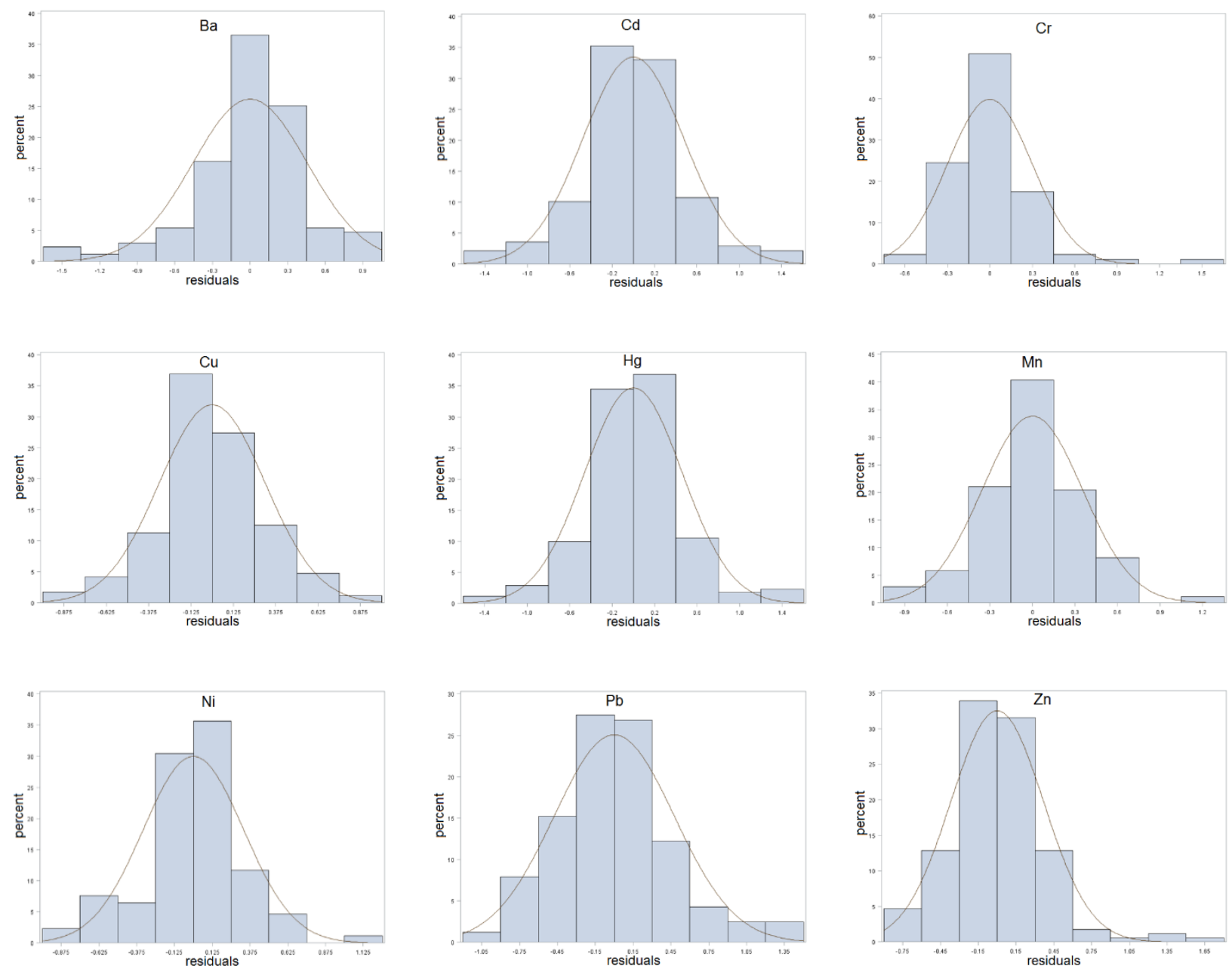

Fig. A-2. Histograms of metal concentrations with normal distribution curves after log transformation 


\section{REFERENCES:}

Alfven, T., Jarup, L. and Elinder, C.G. (2002). Cadmium and lead in blood in relation to low bone mineral density and tubular proteinuria. Environ Health Perspect 110, 699-702.

Al-Momani, I.F. (2007). Trace elements in street and household dusts in Amman, Jordan. Soil \& Sediment Contamination 16, 485-496.

Banfalvi, G. (2011). Cellular Effects of Heavy Metals. Springer Science + Business Medis B.V.

Barregard, L. (2006). Health effects of inorganic mercury. Toxicology Letters 164, S11.

Butte, W. and Heinzow, B. (2002). Pollutants in house dust as indicators of indoor contamination. Rev Environ Contam Toxicol 175, 1-46.

Canadian Council of Ministers of the Environment (CCME; 2014). Canadian Environmental Quality Guidelines, available on http://st-ts.ccme.ca/, retrieved on May 3, 2014.

Charlesworth, S., De Miguel, E. and Ordonez, A. (2011). A review of the distribution of particulate trace elements in urban terrestrial environments and its application to considerations of risk. Environ Geochem Health 33, 103-123.

Chattopadhyay, G., Lin, K.C. and Feitz, A.J. (2003). Household dust metal levels in the Sydney metropolitan area. Environmental Research 93, 301-307.

Cook, A.G., Weinstein, P. and Centeno, J.A. (2005). Health effects of natural dust: role of trace elements and compounds. Biological Trace Element Research 103, 1-15.

Dundar, M.S. and Atundag, H. (2002). Heavy metal determination of house dust in Adapazari, Turkey, after earthquake. Trace Elements and Electrolytes 19, 55-58.

Fergusson J.E. and kim, N.D. (1991). Trace elements in street and house dusts: sources and speciation. Sci. Total Environ. 100, 125-150.

Hassan, S.K.M. (2012). Metal concentrations and distribution in the household, stairs and entryway dust of some Egyptian homes. Atmospheric Environment 54, 207-215.

Health Canada (2009). Indoor air quality and health. Available at http://www.hc-sc.ge.ca/ewhsemt/air/in/qual/index-eng.php, accessed May 26, 2014.

Huang, M., Wang, W., Leung, H. Chan, C.Y., Liu, W.K., Wong, M.H. and Cheung, K.C. (2012). Mercury levels in road dust and household $\mathrm{TSP} / \mathrm{PM}_{2.5}$ related to concentrations in hair in Guangzhou, China. Ecotoxicology and Environmental Safety 81, 27-35.

Jabeen, N., Ahmed, S., Hassan, S.T. and Alam, N.M. (2001). Levels and sources of heavy metals in house dust. Journal of Radioanalytical and Nuclear Chemistry 247 (1), 145-149. 
Kefeni, K.K. and Okonkwo, J.O. (2013). Trace metals, anions and polybromodiphenyl ethers in settled indoor dust and their association. Environ Sci Pollut Res 20, 4895-4905.

Khaparde, V.V., Pipalatkar, P.P., Pustode, T., Chalapati Rao, C.V. and Gajghate D.G. (2012). Influence of burning of fireworks on particle size distribution of $\mathrm{PM}_{10}$ and associated Barium at Nagpur. Environ Monit Assess 184, 903-911.

Khoder, M.I., Hassan, S.K. and El-Abassawy, A.A. (2010). An evaluation of loading rate of dust, $\mathrm{Pb}, \mathrm{Cd}$ and $\mathrm{Ni}$ and metals mass concentration in the settled surface dust in domestic houses and factors affecting them. Indoor and Built Environment 19 (3), 391-399.

Kim, N. and Fergusson, J. (1993). Concentrations and sources of cadmium, copper, lead and zinc in house dust in Christchurch, New Zealand. The Science of the Total Environment 138, 1-21.

Klepeis, N.E., Nelson, W.C., Ott, W.R., Robinson, J.P., Tsang, A.M., Switzer, P., Behar, S.C. and Engelmann, W.H. (2001). The National Human Activity Pattern Survey (NHAPS): a resource for assessing exposure to environmental pollutants. Journal of Exposure Analysis and Environmental Epidemiology, 11, 231-252.

Kramtz, A. and Dorevitch, S. (2004). Metal exposure and common chronic diseases: a guide for the clinician. Dis Mon 50, 220-262.

Kurt-Karakus, P.B. (2012). Determination of heavy metals in indoor dust from Istanbul, Turkey: Estimation of the health risk. Environment International 50, 47-55.

Lau, W.K.Y., Liang, P., Man, Y.B., Chung, S.S. and Wong, M.H. (2014). Human health risk assessment based on trace metals in suspended air particulates, surface dust, and floor dust from e-waste recycling workshops in Hong Kong, China. Environ Sci Pollut Res 21, 38133825 .

Lioy, P.J., Freeman, N.C.G. and Millette, J.R. (2002): Dust: a metric for use in residential and building exposure assessment and source characterization. Environ Health Perspect 110, 969983.

Lisiewicz, M., Heimburger, R. and Golimowski, J. (2000). Granulometry and the content of toxic and potentially toxic elements in vacuum-cleaner collected, indoor dusts of the city of Warsaw. The Science of the Total Environment 263, 69-78.

Loska, K., Cebula, J., Pelczar, J., Wiechula, D., and Kwapulinski, J. (1997). Use of enrichment, and contamination factors together with geoaccumulation indexes to evaluate the content of $\mathrm{Cd}, \mathrm{Cu}$, and $\mathrm{Ni}$ in the Rybink water reservoir in Poland. Water, Air, and Soil Pollution 93,347-365. 
Lu, X., Wang, L., Lei, K., Hunang, J. and Zhai, Y. (2009). Contamination assessment of copper, lead, zinc, manganese and nickel in street dust of Baoji NW, China. Journal of Hazardous Materials 161, 1058-1062.

Lu, X., Zhang, X., Li, L.Y., and Chen,H. (2014). Assessment of metals pollution and health risk in dust from nursery schools in Xi'an, China. Environmental Research 128, 27-34.

Madany, I.M., Akhter, M.S. and Al Jowder, O.A. (1994). The correlations between heavy metals in residential indoor dust and outdoor street dust in Bahrain. Environment International 20 (4), 483-492.

Manta, D.S., Angelone, M., Bellanca, A., Neri, R., and Sprovieri, M. (2002). Heavy metals in urban soils: a case study from the city of Palermo (Sicily), Italy. The Science of the Total Environment 300, 229-243.

Mason, B. and Moore, C.B. (1982). Principles of Geochemistry. $4^{\text {th }}$ edition, John Wiley and Sons, USA.

Mazinanian, N., Hedberg, Y. and Wallinder, I.O. (2013). Nickel release and surface characteristics of fine powders of nickel metal and nickel oxide in media of relevance for inhalation and dermal contact. Regulatory Toxicology and Pharmacology 65, 135-146.

Meza-Figueroa, D., De la O-Villanueva, M., and De la Parra, M. (2007). Heavy metal distribution in dust from elementary schools in Hermosillo, Sonora, Mexico. Atmospheric Environment 41, 276-288.

Morawska, L. and Salthammer (2003). Indoor Environments: Airborne Particles and Settled Dust. Wiley-VCH, Weinheim.

Nriagu, J.O. (1988). A silent epidemic of environmental metal poisoning? Environmental Pollution 50, 139-161.

Popoola, O.E., Bamgbose, O., Okonkwo, O.J. Arowolo, T.A., Popoola, A.O. and Awofolu, O.R. (2012). Heavy metals content in classroom dust of some public primary schools in metropolitan Lagos, Nigeria. Research Journal of Environmental and Earth Sciences 4 (4), 460-465.

Rassussen, P.E., Subramanian, K.S. \&Jessiman, B.J. (2001). A multi-element profile of housedust in relation to exterior dust and soils in the city of Ottawa, Canada. Sci Total Environ 267, 125-140.

Rassussen, P.E. (2004). Can metal concentrations in indoor dust be predicted from soil geochemistry? Can J Anl Sci Spectrosc. 49, 166-174. 
Rustagi, N. and Singh, R. (2010). Mercury and health care. Indian Journal of Occupational and Environmental Medicine 14 (2), 45-48.

Sharpe, M. (2004). Safe as houses? Indoor air pollution and health. Journal of environmental monitoring 6, 46-49.

Tong, S.T.Y. and Lam, K.C. (2000). Home sweet home? A case study of household dust contamination in Hong Kong. The Science of the Total Environment 256, 115-123.

Tran, D.T., Alleman, L.Y., Coddeville, P. and Galloo, J.C. (2012). Elemental characterization and source identification of size resolved atmospheric particles in French classrooms. Atmospheric Environment 54, 250-259.

Turner, A. (2011). Oral bioaccessibility of trace metals in household dust: a review. Environ Geochem Health 33, 331-341.

Turner, A. and Hefzi, B. (2010). Levels and Bioaccessibilities of Metals in Dusts from an Arid Environment. Water Air Soil Pollut 210,483-491.

Turner, A. and Simmonds, L. (2006). Elemental concentrations and metal bioaccessibility in UK household dust. Science of the Total Environment 371, 74-81.

Uduma, A.U., and Awagu, E.F. (2013). Manganese as a reference element for the assessment of zinc enrichment and depletion in selected farming soils of Nigeria. Research Journal of Environmental and Earth Sciences 5 (9), 497-504.

USEPA method "40 CFR Appendix B to Part 136". Protection of environment. Environment Protection Agency, 2005.

USEPA (1999). Mercury in water by oxidation, purge and trap, and cold vapor atomic fluorescence spectrometry. USEPA Method 1631, Revision B. Available at http://www.labservice.it/Downloads/Private/Metodiche_pvt/met-epa1631b.pdf, accessed May $24,2013$.

USEPA (2001). Total mercury in tissue, sludge, sediment, and soil by acid digestion and $\mathrm{BrCl}$ oxidation. Appendix to Method 1631. Available at http://www.tekran.com/files/EPA_1631_Appendix_for_Solids.pdf, accessed May 24, 2013

USEPA (2007). Microwave assisted acid digestion of sediments, sludges, soils, and oils. Available at http://www.epa.gov/osw/hazard/testmethods/sw846/pdfs/3051a.pdf, accessed November 21, 2012.

Vincent, J.H. (2005). Health-related aerosol measurement: a review of existing sampling criteria and proposals for new ones. Journal of Environmental Monitoring 7, 1037-1053. 
Willers, S., Gerhardsson, L., Lundh, T. (2005). Environmental tobacco smoke (ETS) exposure in children with asthma relation between lead and cadmium, and nicotine concentrations in urine. Respir Med 99, 1521-1527.

Yaghi, B., and Abdul-Wahab, S.A. (2004). Levels of heavy metals in outdoor and indoor dusts in Muscat, Oman. Intern. J. Environ. Studies 61 (3), 307-314.

Yap, C.K., Kkrishnan, T. and Chew, W. (2011). Heavy metal concentrations in ceiling fan dusts sampled at schools around Serdang area, Selangor. Sains Malaysiana 40 (6), 569-575. 